\title{
LA ARQUITECTURA EFÍMERA, LA CIUDAD Y EL JARDÍN. EL CASO DEL JARDÍN VICTORIA, EL HOTEL TAORO Y LA EXPOSICIÓN DE HORTICULTURA DE 1888
}

\author{
Jesús Rodríguez Bravo* \\ Consejería de Educación y Universidades del Gobierno de Canarias
}

\section{RESUMEN}

El arte efímero ofrece una gran libertad creativa, tiene un fuerte carácter evocador y se nutre de variadas referencias estilísticas. Su asociación al jardín es una cuestión clásica, pero que alcanza su máxima expresión en el siglo xix a raíz del cambio de la sociedad y de las consecuencias de la Revolución Industrial. Canarias ofreció, en esa época, el cariz más amable de esos cambios y sus espacios públicos se convirtieron en lugares de ocio, embellecidos con templetes, pabellones o kioscos, muchos con carácter efímero, como los construidos para la Exposición Provincial de Horticultura de 1888, una de las muestras más importantes del fin de siglo y ejemplo sintomático de cómo la naturaleza encontró en las ciudades un espacio en el que renacer.

Palabras clave: arte efímero, arquitectura efímera, Canarias, La Orotava, Puerto de la Cruz, horticultura, exposiciones universales, orientalismo, naturaleza, siglo XIX.

\section{EPHEMERAL ARCHITECTURE, THE CITY AND THE GARDEN. THE CASE OF THE VICTORIA GARDEN, THE TAORO HOTEL AND THE 1888 HORTICULTURAL EXHIBITION}

\section{Abstract}

Ephemeral art offers great creative freedom, has a strong evocative character and is nourished by a variety of stylistic references. Its association with the garden is a classic question, but it reached its maximum expression in the 19th century following the change in society and the consequences of the Industrial Revolution. At that time, the Canary Islands offered the kindest aspect of these changes and their public spaces became places of leisure, embellished with temples, pavilions or kiosks, many of them ephemeral in nature, such as those built for the 1888 Provincial Horticultural Exhibition, one of the most important exhibitions of the end of the century and a symptomatic example of how nature found in cities a space in which to be reborn.

KeYwords: ephemeral art, ephemeral architecture, Canary Islands, La Orotava, Puerto de la Cruz, horticulture, universal exhibitions, orientalism, nature, 19th century. 


\section{DEL ILUSTRADO SIGLO XVIII AL CONVULSO SIGLO XIX}

Aunque pudiera parecer lo contrario, el paso de un siglo a otro fue todo menos tranquilo. El Setecientos había sido un período de evolución en las mentalidades que afectó a todos los aspectos de la vida cotidiana, desde la forma de vestir hasta la forma de pensar. Y cuando comenzó el siglo XIX ya se había recorrido un camino incierto pero inexorable, que había liquidado el Antiguo Régimen y abriría las puertas a un cambio social realmente considerable a finales de la centuria. El desarrollo de estas ideas tuvo en Canarias un efecto limitado porque las islas eran un territorio escaso comparado con la dimensión que alcanzaron los movimientos sociales a nivel europeo. Sin embargo, si nos atenemos a los sucesos con los que comenzó el siglo, habría que pensar que, efectivamente, nada iba a suceder con calma. Los autores que se han acercado a este período histórico complejo y que han analizado los hechos acaecidos al iniciarse el Ochocientos o los textos que han llegado hasta nosotros de la prensa o de escritores y cronistas coetáneos nos hablan de acontecimientos diversos, convulsos y hasta traumáticos vividos en la España decimonónica.

Habría que preguntarse cómo influyeron estos acontecimientos en el devenir de un siglo que supuso un gran cambio en la vida social de las personas o en los modos de entender los estamentos de la sociedad y cómo todo ello se reflejó en la conformación de las ciudades, incluidos sus jardines. Los primeros cincuenta años del xIX son realmente complicados, sobre todo a nivel político, pero también económico. No obstante, las aspiraciones que hicieron acelerar el comienzo de la centuria fueron transformándose poco a poco en deseos frustrados, lo que creará un poso de conflicto que no tardará en aflorar y que acompañará a todo el siglo. Por otro lado, la segunda mitad significó la consolidación de la burguesía y la extensión de cierto conservadurismo que convivió con las nuevas demandas sociales. En España y bajo el reinado de Isabel II, se consolidó también un modelo liberal constantemente intervenido desde la política y el estamento militar. Estos cambios sociales definieron a la nueva sociedad, caracterizada por el movimiento del campo a la ciudad, menos notorio en unas islas aún volcadas hacia la agricultura, y por los nuevos gustos estéticos, asociados a una burguesía que encontró en los movimientos arquitectónicos modernos el reflejo perfecto de su nuevo estatus. Estos y otros acontecimientos habían influido en el pensamiento de importantes científicos, escritores o simples observadores de la realidad que reflexionaban ya sobre la relación del ser humano con la naturaleza y la defensa de los efectos que esta tenía sobre el planeta. Esto nos ayuda a comprender por qué estas nuevas corrientes de pensamiento social y científico tuvieron efecto en la difusión del positivismo unido a la evolución de la humanidad y cómo, a escala local, personajes como Antonio Lugo

* Historiador del arte. Consejería de Educación y Universidades del Gobierno de Canarias. jesusrodriguezbravo@gmail.com. 


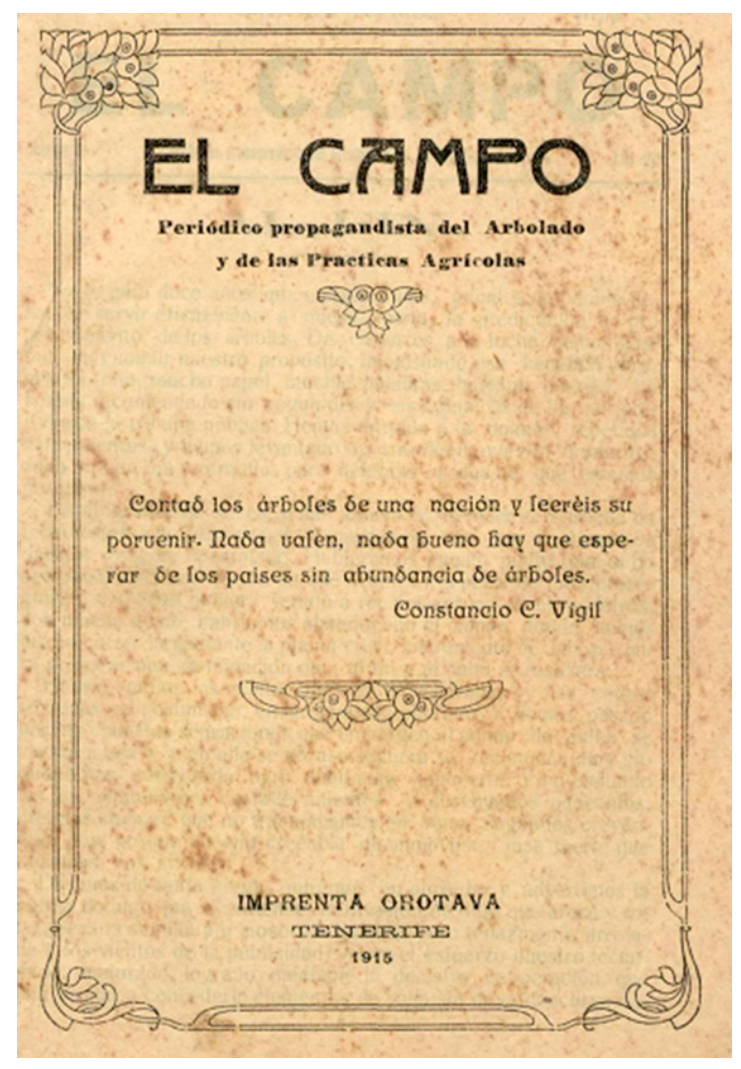

Fig. 1. Portada de la revista El Campo, editada y dirigida por Antonio Lugo y Massieu.

y Massieu serán un ejemplo claro de un progreso entendido en beneficio de todos, incluido el planeta (fig. 1).

Los cambios afectaron también a una incipiente tecnología, vinculada a la aparición de la luz eléctrica, los nuevos medios de transporte o el uso del hierro y el vidrio como nuevos materiales constructivos. Como consecuencia, se ampliarán las carreteras y se adecuarán progresivamente al coche a motor; surgirán los servicios eléctricos; o empezarán a proliferar balcones de hierro forjado, verjas de formas sinuosas o caprichosas decoraciones arquitectónicas obtenidas de la ductilidad del cemento a partir de moldes de madera. Será el triunfo de la casa burguesa, de los eclecticismos, de los jardines exteriores con amplias verjas circundantes, de la naturaleza a pie de calle y por extensión de la arquitectura que llamamos efímera, cuya vocación era simbólica y ornamental y sin pretensiones de durar en el tiempo.

Aunque Canarias no se vio afectada de forma decidida por los efectos de la Revolución Industrial en la transformación de las ciudades, es curioso cómo sí lo hizo en cuanto al nuevo urbanismo que surgió de ella. Nos referimos a la uto- 
pía de una ciudad residencial, destinada casi exclusivamente a la clase burguesa y aislada de los sectores más desfavorecidos de la sociedad. Este concepto va unido a los ensanches vividos en muchas ciudades europeas a través de la urbanización reticular y que vemos singularmente en Santa Cruz de Tenerife una vez que se traza la Rambla y se urbanizan los barrios aledaños, algunos de los cuales se conformaron como pequeños lugares residenciales con casas diseñadas por los arquitectos del momento ${ }^{1}$. Los planes diseñados para París, Barcelona o Londres fueron conocidos y tuvieron más que una aplicación práctica una influencia conceptual en las islas, en la medida en que se primaron los trazados regulares, las ciudades jardín o las viviendas unifamiliares.

Lógicamente, los avances científicos y las reformas urbanas no iban del todo a la par que los cambios sociales, pero las sociedades de los siglos XVIII y XIX se ven desde nuestra perspectiva actual muy diferentes entre sí. También es evidente que las ciudades canarias de la segunda mitad del siglo XIX no tienen las características de las grandes urbes europeas, ni siquiera en el caso de las dos capitales, donde sí se dan estos planteamientos, aunque con matices, pero sí que hay en ellas ciertos aspectos que trazan, aunque sea localmente, nuevas vías de urbanización bajo ese concepto novedoso de regreso a la naturaleza.

Por lo tanto la sociedad se debatía entre las ideas liberales y la crisis económica, o entre cierta movilización de los sectores más pobres de la sociedad y la necesidad de continuar con el sistema tradicional entre los más acomodados. Sin embargo, al alcanzar la segunda mitad del siglo, muchos movimientos de origen burgués o cuando menos más aperturistas, dieron un impulso decisivo a la transformación de la vida cotidiana. Las ideas surgidas de la nueva dimensión que comenzaron a adquirir las grandes ciudades europeas como París o Londres, donde, frente a los efectos de la Revolución Industrial, surgió un espíritu de acercamiento a la naturaleza, llegaron a las islas, como lo habían hecho desde el siglo XVIII, a los ámbitos más formados de la sociedad, y tuvieron en la figura de ciertos personajes decisivos de la vida política y cultural unos excelentes vehículos propagadores. A figuras anteriores como Humboldt tenemos que sumar los nombres de otros naturalistas como el inglés Philip Barker Webb o los franceses Sabino Berthelot y Pierre Alexander Auber o personajes tan ilustres como los hermanos Betancourt y Castro, el portuense José Agustín Álvarez Rixo o el citado Antonio Lugo y Massieu².

1 Gónzález Chávez, Carmen Milagros (1988): «La rambla del general Franco: elemento generador de la trama urbana», en VIII Coloquio de historia canario-americana. Las Palmas de Gran Canaria: Cabildo Insular; y Hernández Gutiérrez, Sebastián y González Chávez, Carmen Milagros (2008): "Arquitectura para la ciudad burguesa. Canarias, siglo XIX», en Historia cultural del arte en Canarias, tomo vi. Santa Cruz de Tenerife: Gobierno de Canarias.

${ }^{2}$ Philip Barker Webb (1793-1854), uno de los más afamados botánicos de la época, llegó a Canarias de camino a Brasil hacia 1828 y aquí entabló amistad con Sabino Berthelot (1794-1880), que se había establecido en 1820. Juntos se dedicaron a elaborar la gran obra Historia natural de las Islas Canarias, publicada en París entre 1835 y 1850. El botánico francés Pierre Alexander Auber (17861843) fue nombrado director del Jardín Botánico de La Habana en 1835, que había sido fundado en 1817, con una doble perspectiva botánica y farmacéutica. Se interesó sobre todo por el estudio de la 
Por otro lado, la prensa escrita se convirtió en la gran difusora de las nuevas ideas y también espejo de la lucha entre las diversas formas de pensamiento ${ }^{3}$. La difusión de las exposiciones universales de finales de siglo gracias a las revistas, el desarrollo de avances técnicos y científicos o la amplia implantación en Canarias de los historicismos arquitectónicos, como la interesantísima gama de viviendas de tipo victoriano, se convirtieron en el eje de los cambios urbanos, que si bien se empezaron a desarrollar desde las últimas décadas del siglo XIX, encontrarán su pleno desarrollo en las primeras del xx.

A la par que todo esto sucedía en el seno de la sociedad, la dimensión urbana de los cambios llegó a la conformación de las ciudades. La apertura de nuevas vías de comunicación, el gusto por el saneamiento de las calles, las fuentes públicas, la aparición de las plazas como lugares de encuentro, los movimientos de arbolado de carreteras y jardines o la vocación naturalista de muchos de los dueños de estos últimos dieron como resultado un cambio político enca minado a abrir las poblaciones al disfrute de sus ciudadanos o, como era costumbre decir en la época, a "embellecer» los espacios públicos.

Evidentemente, todos estos cambios no se produjeron en una sociedad idílica. Las diferencias entre clases que venían manifestándose desde siempre continuaron existiendo y en ciertos aspectos podría afirmarse que aumentaron, ya que algunos sectores aristocráticos no querían perder sus privilegios y la nueva burguesía emulaba los modos de la nobleza. En unas ciudades eminentemente agrícolas, la brecha social entre un campesinado pobre y una alta sociedad caciquil seguía siendo enorme. Sin embargo, no hay que olvidar que es precisamente en esta época cuando comienzan a cuestionarse muchos de los principios que hasta ese momento sustentaban la estratificación social. El cambio sería largo y conllevaría momentos de lucha, a veces cruenta. Y a finales del siglo xix la sociedad ya no sería la misma, aunque conservara reductos de un pasado heredado difíciles de erradicar. El cambio urbano experimentado en muchas de las poblaciones canarias entre el final del XIX

\footnotetext{
flora cubana. Fue colaborador de Berthelot, con quien fundó un Liceo en La Orotava para modernizar la enseñanza y que fue suspendido en 1827. Estuvo en Canarias entre 1824 y 1832, cuando marchó a Cuba. Véanse Herrera Piqué, Alfredo (1976): «Webb y Berthelot, investigadores de la naturaleza canaria», en Aguayro, n. ${ }^{\circ} 71$, pp. 8-12. Las Palmas de Gran Canaria: Caja Insular de Ahorros de Canarias; AA. VV. (2012): «El jardín botánico y la botánica farmacéutica en la Habana del siglo XIX», en Ars Pharmaceutica, n. ${ }^{\circ}$ 53. Granada: Universidad de Granada, pp. 34-39; Puig-SAmper, Miguel Ángel y Valero, Mercedes (2017): «A. Auber y el Jardín Botánico de La Habana», en Nouveau Monde et renouveau de l'histoire naturelle, vol. III. París: Presses Sorbonne Nouvelle; y Wolf, Andrea (2017): La invención de la naturaleza. El nuevo mundo de Alexander von Humboldt. Madrid: Taurus, Penguin Random House.

3 Rodríguez Mesa, Manuel (1985): Desde el Falansterio al Liceo de Taoro. Santa Cruz de Tenerife, p. 25 y siguientes. El desarrollo de la prensa tal como la entendemos debe situarse en la segunda mitad del xIX, momento en el que son numerosas las publicaciones de carácter periódico. Véase AA. VV. (1986): La prensa del Valle de La Orotava (1880-1930). Puerto de la Cruz: Aula de Cultura del Excmo. Ayuntamiento del Puerto de la Cruz.
} 
y el inicio del xx es un buen reflejo de esa aceleración social y de la frenética sucesión de acontecimientos. La ciudad tampoco sería ya la misma.

\section{LA NATURALEZA TOMA LAS CIUDADES}

La naturaleza y el urbanismo ligaron sus destinos a finales del siglo XIx. Las ciudades habían dado la espalda al campo tras la Revolución Industrial, lo que provocó la necesidad de un retorno a lo natural, pero de una manera cuando menos curiosa, pues fue la naturaleza la que entró en las ciudades. Y lo hizo a través de los jardines y las plazas arboladas, de los ensanches y de algunos movimientos en defensa de la arborización; y en el ámbito privado los jardines traseros e íntimos se mudaron a la calle para ser vistos y compartidos. Es cierto que Tenerife en esa época tenía un carácter fuertemente agrícola y que Canarias no sufrió los efectos de una industrialización en ocasiones desmedida, pero sí vivió las consecuencias del cambio, de manera significativa en el campo de la arquitectura. Surgieron entonces nuevos estilos estéticos que supieron aprovechar aquel deseo social de volcarse hacia el goce y el disfrute de los espacios, y artistas capaces de dar rienda suelta a las inquietudes de unos propietarios favorecidos por mejoras económicas, aunque fueran transitorias, como el auge de la cochinilla.

En ese incierto camino en que se convirtió el cambio de siglo, tuvieron influencia muchos y diversos acontecimientos, como la consolidación y creación de los jardines botánicos o la decisiva Exposición de Horticultura organizada en 1888, ejemplo singular de un activismo medioambiental prematuro que aunaba el estudio de las plantas con lo artístico y que favoreció indirectamente otras acciones posteriores; o el influjo que los jardines de este período recibieron de las corrientes naturalistas y victorianas y que se dejaron sentir también en lugares alejados del centro urbano, como las numerosas haciendas diseminadas por Tenerife, en las que se desplegaron soluciones arquitectónicas muy interesantes y espacios ajardinados de todo tipo, en los que se tuvo muy en cuenta la nueva relación que el ciudadano había entablado con la naturaleza. Espacios que se vieron enriquecidos con templetes, kioscos, esculturas... que los dotaban de un carácter simbólico y singular.

Esta historia en la que se unen urbanismo y naturaleza no acaba, lógicamente, en los albores del siglo xx. Más bien al contrario, el siglo xix puso las bases de una cultura natural que tuvo en la primera mitad del nuevo siglo un desarrollo muy destacado, favorecido por el giro romántico de las ciudades hacia todo lo que tenía que ver con el retorno a un pasado que se veía cautivador; pero también con la mirada puesta en un futuro en el que la arquitectura y el paisajismo tomaran un nuevo camino.

Ya desde los años ochenta del siglo XIX se habían diseñado en algunas ciudades europeas barrios residenciales bien comunicados y en 1898 Ebenezer Howard había publicado su libro Ciudades jardín del mañana, en el que intentaba aproximar de nuevo al hombre civilizado a la naturaleza. Las nuevas ciudades demandaban nuevos equipamientos civiles como escuelas, bibliotecas o espacios para la administración, pero también lugares de encuentro y disfrute, como teatros, parques o 
plazas ${ }^{4}$. Eran lugares de ocio e intercambio social que necesitaban de cierta idea de ornato, de ahí que solieran ir acompañados de algunas pautas urbanísticas comunes, como el distanciamiento entre las edificaciones y la arborización. Estéticamente era una ciudad netamente diseñada para el goce visual, pero también para el deleite y la respiración urbana. La necesidad de volver las ciudades más habitables encontró en la aparición de la luz eléctrica un aliado importantísimo. Es un ejemplo de un desarrollo industrial que fue favorable para las urbes, alejadas como estaban del campo. También la creación de las ciudades jardín, vinculadas a la búsqueda de la belleza y al recurso de traer la naturaleza a la ciudad, reconvirtió las poblaciones en lugares agradables, con plantas y flores. Estas ideas calaron en la Europa decimonónica y llegaron a Canarias transformadas en parte en una ilusión estética, pues los daños de la Revolución Industrial no eran visibles aquí. Además, se unieron a una tradición muy ligada al valle de La Orotava, como era la exuberancia vegetal del entorno, aún no demasiado transformado. Las ciudades canarias tomaron la escenografía urbana de una urbe más habitable en el marco de una estética arquitectónica visiblemente atractiva y el ciudadano de a pie se impregnó de esa cultura del goce a través de la naturaleza, pero en el marco de la ciudad habitada.

En ese sentido, varios son los hechos vividos a lo largo del Ochocientos en el valle de La Orotava que nos llevan a considerar que esta idea se venía gestando en la sociedad desde mucho antes. Por ejemplo, la creación de las alfombras de flores es uno de los antecedentes más importantes en relación con el gusto por el embellecimiento de la población, una tradición que se remonta a 1846 o 47 que ejemplifica el gusto hacia lo natural que se impondrá en las décadas siguientes 5 . El gusto por el cuidado de la naturaleza y por despertar entre los ciudadanos un espíritu de conservación y difusión tuvo un importante empuje en la denominada Fiesta del árbol. A finales de 1897 se recibió un oficio de la Comisión Provincial de Madrid de la primera fiesta de este tipo, celebrada el 26 de marzo de 1896 en la capital, para que se secundara la idea y se celebrara ese mismo año en otros lugares ${ }^{6}$. Se buscaba difundir la función

${ }^{4}$ Sobre esta idea véase Gamboa Samper, Pablo (2003): «El sentido urbano del espacio público», en Revista Bitácora, n. ${ }^{\circ}$ 7, pp. 13-18. Bogotá: Universidad Nacional de Colombia.

${ }^{5}$ Para ampliar este tema véanse RodríGuez MazA, José Manuel (1997): Las alfombras de La Orotava. Una historia de arte y devoción; Hernández Gutiérrez, Sebastián (1997): El jardín artificial. Crónica de ciento cincuenta años de alfombrismo en La Orotava (1847-1997). Cabildo Insular de Tenerife; Rodríguez MAzA, José Manuel (2000): «Origen e historia de las alfombras de flores de La Orotava», en Catharum, n. ${ }^{\circ}$ 2. Puerto de la Cruz: Instituto de Estudios Hispánicos de Canarias; Hernández Gutiérrez, Sebastián (2007): El arte de las alfombras del Corpus de La Orotava. Patrimonio cultural canario. La Orotava: Ayuntamiento de La Orotava y Asociación de Alfombristas; y Hernández Murillo, Pedro (2018): Ritual, arena y flor. El arte efímero de las alfombras de La Orotava. Ed. Idea, Santa Cruz de Tenerife.

${ }^{6}$ Esta fiesta había sido promovida por el ingeniero Ricardo Codorníu Stárico y apoyada por el Ayuntamiento y la Diputación de la capital. Tuvo una enorme afluencia y éxito, con participación de la Casa Real y numerosos políticos, pero también un gran coste, por lo que no tuvo continuidad en el tiempo. 
de los bosques como elementos ecológicos y sociales 7 . Las fiestas del árbol proliferaron por toda España entre aquella primera fecha madrileńa y 1936, promoviendo lo que entonces se denominó causa forestal. Desde los sectores políticos se fomentó una fiesta que tenía un carácter lúdico e implicaba a muchos sectores de la sociedad, viéndose con buenos ojos desde todas las tendencias políticas y estamentos sociales, por lo que prosperó bastante, aunque con altibajos, hasta la Guerra Civil. No podemos olvidar que estas circunstancias se dieron en un momento de intensa preocupación por el cuidado y regeneración de los montes y que había tenido su reflejo político en la creación de la Administración Forestal Española y el cuerpo nacional de ingenieros de montes en esas mismas fechas ${ }^{8}$. En años sucesivos la fiesta se consolidó como acto de defensa repobladora y educativa y en 1915 un real decreto la instauró con carácter nacional. Solamente un poco antes, concretamente a finales de 1914, el guarda mayor de la comarca forestal de La Orotava, Nicolás Tolosa Díaz, solicitó al Ayuntamiento celebrar la fiesta del árbol, aprobándose la propuesta y autorizando el plantio de árboles en los sitios públicos ${ }^{10}$. La fiesta tuvo lugar el 21 de marzo, plantándose ejemplares en el paseo de la Cruz del Teide y el camino de La Perdoma. El éxito hay que medirlo teniendo en cuenta las dimensiones locales del evento pero también sin olvidar las numerosas personalidades que en esos años fomentaban el arbolado de carreteras y plazas ${ }^{11}$. Un aspecto que no queremos dejar pasar sobre esta celebración es la importancia que se le concedió al ajardinamiento de las ciudades o al desarrollo posterior de viveros y de una cultura del árbol realmente importante, siendo un reflejo significativo del cambio en el concepto urbano pero también de la conservación de los entornos naturales. Los establecimientos de venta de plantas cultivadas y árboles proliferaron en la segunda mitad del siglo xIx, ayudados por la difusión hecha a través de las publicaciones periódicas. Establecimientos como los de Vicente Roca, horticultor valenciano, o del aragonés Mariano Cambra, se anunciaban en

7 En La Orotava, la propuesta se pasó a la comisión de festejos y montes, pero no será hasta años después cuando tengamos nuevas noticias del acontecimiento. Al comenzar 1897 se había agradecido la labor del síndico Guardia por haber donado las maderas para la construcción de las jaulas para la defensa de los árboles recién plantados en sitios públicos. Archivo Municipal de La OroTAVA (en adelante AMLO), Libro de actas, 15 de enero y 18 de noviembre de 1897.

${ }^{8}$ A raíz de su celebración se fundó en el mismo año la Sociedad de Amigos de los Árboles de Madrid, siguiendo el modelo de las aparecidas en Francia. Sierra Vigil, José Miguel (2011): La culta y simpática fiesta: la fiesta del árbol en la política forestal y la historia de España. Madrid: Ministerio de Medio Ambiente y Medio Rural y Marino. Las elevadas pretensiones de la fiesta en Madrid y la polémica periodística a cuenta de su coste acabaron con la iniciativa, que volvería a renacer en 1899, pero en este caso en Barcelona, gracias a la iniciativa de Rafael Puig y Valls. La cita barcelonesa tuvo un enorme éxito entre las distintas sociedades culturales, educativas, científicas y profesionales, que no tardaron en adherirse a la propuesta, con un marcado objetivo hacia la participación de los colegios y un enorme carácter cívico.

${ }^{9}$ Gaceta de Madrid, n. ${ }^{\circ}$ 272, 30 de septiembre de 1904.

${ }_{10}$ AMLO, Libro de actas, 17 de diciembre de 1914, f. 19v.

11 AMLO, Libro de actas, 6 de mayo de 1915, f. 46v. La fiesta siguió celebrándose por toda España hasta el estallido de la Guerra Civil, aunque posteriormente tuvieron lugar otras en los ańos cuarenta, pero sin la continuidad anterior. 


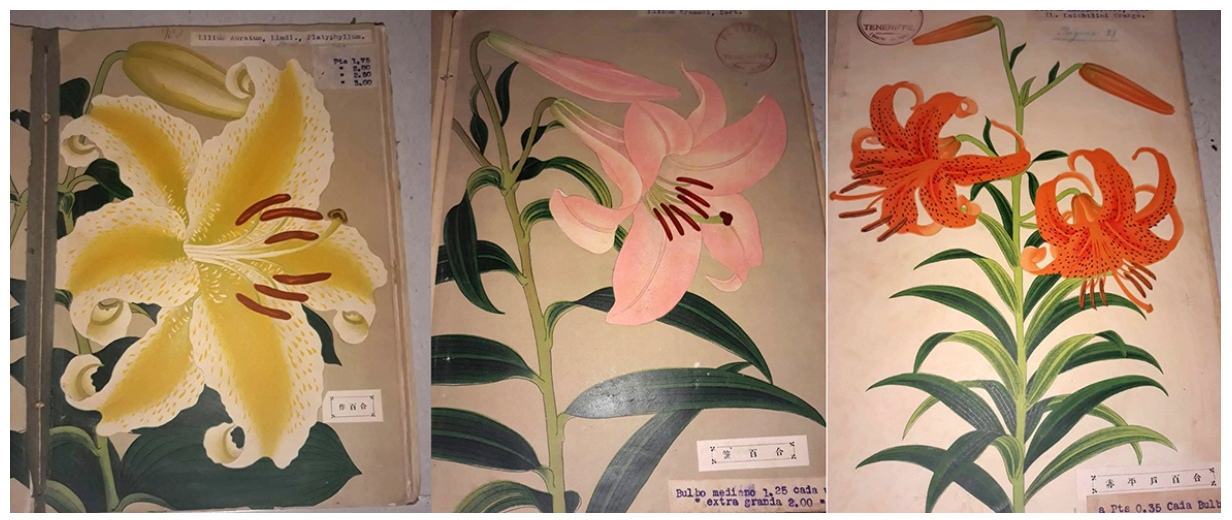

Fig. 2. Detalles del catálogo de lirios japoneses de Federico C. Varela. Colección particular.

revistas y hacían catálogos para toda España. Viveros como la Quinta de la Esperanza, en Madrid, fundado en 1848, cosecharon numerosos premios en las exposiciones de horticultura de la capital. Algunos llegaron a publicar catálogos de semillas o manuales de jardinería, como el portugués José Marqués Loureiro, quien desde Oporto enviaba por correo paquetes de semillas a toda Europa; o Juan Nonell, autor de la Guia del jardinero y tratado de arboricultura, publicada en Barcelona en 1869. Otro tipo de publicaciones, como la Revista hortícola andaluza de Francisco Ghersi, con números mensuales entre 1881 y 1885, alentaban el cultivo y la exposición. Algunas casas ofrecían también el diseño de jardines entre sus trabajos. Fantásticos fueron los anuncios de la empresa Vilmorin-Andrieux, cuyas ilustraciones en sus catálogos generales de flores y plantas eran verdaderos reclamos visuales a finales del siglo XIX. Y en el caso de Tenerife, la labor de Federico Carlos Varela en el mercado hortícola y en la introducción de algunas especies, como el lirio japonés, fue muy relevante y dejó numerosas referencias en la prensa de la época, así como un maravilloso catálogo que servía como reclamo a particulares (fig. 2). Desde su sede en la santacrucera calle de Méndez Núnéz, Varela se publicitaba en los periódicos de principios del siglo Xx como la empresa de semillas y otros productos para el campo más confiable en la isla. Además, era frecuente encontrarlo en las secciones de sociedad de la prensa, que se hacía eco de sus viajes a la Península, y sus productos llegaron a anunciarse en los periódicos británicos. Llegó a tener una sección de jardinería en Gaceta de Tenerife en los años veinte, en la que escribía sobre floricultura y horticultura.

Pero tal vez uno de los antecedentes más importantes en el concepto de naturaleza urbana sea el empuje dado al estudio en el marco de los jardines botánicos, verdaderos laboratorios vegetales. Es lo que ocurre con el Jardin de Aclimatación de La Orotava, que podemos ver en un fantástico grabado salido de la mano del inglés J.J. Williams y publicado en la obra Misceláneas Canarias de Sabino Berthelot en 1839, y que nos muestra un espacio intensamente arbolado rodeado por un sencillo muro perimetral de mampuesto. Se trata de una de las imágenes más difundidas de este antiquísimo jardín, fundado a iniciativa del marqués de Villanueva del Prado, 
Alonso de Nava y Grimón, bajo Real Orden de Carlos III en 1788 y que comenzó a funcionar como tal en 1791, cuyo objetivo principal era la aclimatación de especies tropicales en un medio más apropiado. Sus planos se debieron al arquitecto Diego Nicolás Eduardo y fueron concebidos como lugar de experimentación y laboratorio para el estudio de las plantas y la obtención de semillas, un espacio definido por André-Pierre Ledru como el paraje más apropiado para la transmigración ${ }^{12}$. A Ledru debemos el primer catálogo de las especies existentes en el jardín en 1795-96, realizado a petición del marqués y en colaboración con Le Gros.

La historia de este jardín es larga, no en vano fue el segundo jardín botánico establecido en España, tras el Real Jardín Botánico de Madrid, que había sido creado en 1755 y trasladado al paseo del Prado en 1781 junto a otras instituciones científicas, con la pretensión de ubicar también el observatorio astronómico y un gabinete de historia natural, edificio que hoy ocupa el Museo del Prado. Ambos no sólo eran lugares de experimentación, sino también de disfrute de los ciudadanos. El Jardín de Aclimatación de La Orotava se vio favorecido ante la inviabilidad de mantener especies tropicales en Madrid y con el transcurso de los años hubo personalidades vinculadas a él que sobrepasan incluso la propia entidad del espacio botánico. Es el caso de Sabino Berthelot, que asumió su dirección en 1820. También del botánico Barker Webb, llegado a las islas en 1828 y que junto con el primero herborizó y publicó en 1834 su famosa Historia Natural de las Islas Canarias. Estas dos figuras son por sí solas suficientes para entender la importancia adquirida por el jardín. Sin embargo, no podemos olvidar el paso de Humboldt o la personalidad de Hermann Wildpret, dedicado prácticamente toda su vida al cuidado de este espacio ${ }^{13}$;

12 Podemos ver una reproducción del grabado de Williams en Rodríguez Hernández, Masu (2010): Imágenes de Canarias. 1764-1927. Historia y ciencia. La Orotava: Fundación Canaria Orotava de Historia de la Ciencia, p. 93.

${ }^{13}$ El suizo Hermann Wildpret, o Germán, tal y como aparece de forma habitual en la documentación de la época, llegó a Tenerife en 1860 y fue un personaje muy importante vinculado a la venta de semillas pero también al estudio y conservación del Jardín de Aclimatación de La Orotava, en el que estuvo durante treinta años. Véase Santos Guerra, Arnoldo (2008): «Paseando entre jardines», en Rincones del Atlántico, n. ${ }^{\circ}$ 5, pp. 194-257. La Orotava; y Matos, Rafael (2000): «Hermann Wildpret, un suizo en el Tenerife del siglo xix. Microanálisis de los mecanismos de la diversificación", en Catharum, n. ${ }^{\circ}$ 2. Puerto de la Cruz: Instituto de Estudios Hispánicos de Canarias. Una de las mejores descripciones que se han hecho de él la encontramos en la Gaceta agricola del Ministerio de Fomento del año 1878, en la que, al describir el jardín, se dice de Wildpret lo siguiente: «El jardinero Germán Wildpret, quien con una actividad sorprendente y con un amor a la naturaleza que encanta, se dedica por completo y consagra su vida entera á sus queridas plantas, a las que profesa verdadera idolatría, solo comparable al amor sincero que a su familia tiene. Wildpret es un modelo de jardinero, y el verdadero tipo del suizo sobrio, activo y laborioso, amante de su país y de su familia, y más que ningún canario entusiasta admirador de la naturaleza de estas islas, de las que se considera ya como hijo adoptivo, por los muchos ańos que de residencia lleva en ellas. Él es jardinero por afición y no por lucro; el dia que se viese separado de su destino se moriría de pena; si fuera rico viviría, lo mismo que ahora, entre las plantas; no viene naturalista a estas islas que no pueda contar en él con un guía inteligente y un excelente compañero y amigo; para él no hay españoles, ni ingleses, ni alemanes, ni franceses, todos son de su familia con tal que sean amantes de la naturaleza. Es, 
tampoco a una personalidad como Ubaldo Pimienta y Urtusáustegui, director del mismo entre 1873 y $1888^{14}$.

Decía Alexander von Humboldt que «el establecimiento de un jardín botánico en Tenerife es una idea sumamente feliz, a causa de la doble influencia que pueda ejercer este jardín sobre los progresos de la botánica y en la introducción de vegetales útiles en Europa $»^{15}$. El científico alemán lo había visitado cuando apenas contaba con diez años de vida y ya era una referencia en Europa. Casi un siglo después, en 1893, lo visitó Daniel Morris, un prestigioso botánico miembro de numerosas sociedades científicas. Estuvo en el jardín y elogió el trabajo de Wildpret por haberle dedicado los últimos treinta ańos de su vida a su cuidado; analizó la flora canaria y describió los ejemplos de la misma que había en el Jardín Botánico de Londres, conocido como Kew Gardens, donde existían más de cien especies canarias cultivadas. En su discurso ante la Royal Horticultural Society, leído en 1895, hizo un recorrido exhaustivo por la vegetación canaria, describiendo el jardín y resaltando que su influencia «en la introducción de nuevas plantas en Canarias es perceptible en todas partes. Durante cien años este jardín ha introducido y distribuido a través del archipiélago algunos de los más preciosos y bellos objetos de cultivo encontrados en cualquier parte del mundo» ${ }^{16}$. Tal fue la fama de este jardín.

En pleno siglo xix el desarrollo de estos jardines botánicos se produjo a la par que otros hechos. Por ejemplo, se puso de moda el coleccionismo de especies raras. En 1863 se promulgó una real orden para que se remitieran a la Península desde las colonias semillas de árboles y plantas ${ }^{17}$; aparecieron publicaciones especializadas y el efecto llegó al jardín privado, convirtiéndose en pequeños campos de experimentación influidos por la corriente europea que llegaba a través de revistas y periódicos, pero también con los extranjeros que empezaron a residir en las islas de forma permanente. Se iniciaron también las exposiciones y los premios y Canarias llega a ser citada en la revista La España en octubre de 1857 como lugar donde ya se había experimentado en exposiciones, junto con Puerto Rico, Andalucía y País $V_{a s c o}{ }^{18}$. Junto con estos acontecimientos cobran importancia las exposiciones universales, como la de Londres de 1851, en las que Paxton y Loudon desarrollaron conceptos ligados al regreso a la naturaleza. Las imágenes asociadas a estas exposiciones son clave para entender la influencia que la libertad creativa que se daba en estas exhibiciones ejerció en el diseño de elementos ornamentales mucho más allá

en una palabra, Wildpret el único hombre capaz de hacer con tan poco dinero en tan poco espacio un tan hermoso y variado jardín, siendo verdaderamente digno de que la patria le esté agradecida».

${ }_{14}$ Sustituido en 1888 por Baltolomé Belza Monagas. Las Canarias, 28 de diciembre de 1888.

${ }^{15}$ Humboldt, Alexander von (2014): Las Islas Canarias. Santa Cruz de Tenerife: Asociación Cultural Humboldt, p. 92.

16 Morris, Daniel (1895): «The plants and gardens of the Canary Islands», en Journal of the Royal Horticultural Society. Discurso leído el 14 de mayo de 1895.

${ }^{17}$ Lasso de la Vega Westendorp, Blanca (2015): Plantas y jardines en la Málaga del siglo XIX. El caso singular de la Hacienda La Concepción, Universidad de Málaga, p. 30.

${ }^{18}$ Idem. 
de los grandes centros europeos. El desarrollo de la fotografía, que a su vez formaba parte de las exposiciones como elemento novedoso, propició que muchas publicaciones pudieran acompañar los textos con aquellas imágenes tomadas de un mundo real, reproduciéndolas a través de distintas técnicas, pero que agrandaron los márgenes de la imaginación de sus lectores en la segunda mitad del siglo $\mathrm{XIX}^{19}$. Con las exposiciones no sólo se fomentaba la difusión, el conocimiento y la experimentación, alentada por los premios concedidos, sino que se iba cambiando gradualmente la idea y el paisaje de la ciudad. Este embellecimiento estaría ligado principalmente a las familias acomodadas, las únicas capaces de invertir en la renovación estética que iba unida al jardín y en última instancia a las corporaciones locales o instituciones filantrópicas.

La Orotava y el Puerto de la Cruz vivieron una transformación urbana notable en sus espacios públicos y a nivel paisajístico en la segunda mitad del siglo XIx. Es el caso de la urbanización de la plaza de Franchi Alfaro, conocida durante muchísimo tiempo como Llano de San Sebastián, por ser un espacio raso junto a la antigua ermita del santo hospitalario. Se trataba de «un terreno sinuoso y escarpado», un descampado cuya urbanización comenzó en agosto de $1867^{20}$ a través de la Sociedad Constructora de Edificios. En 1879 el italiano Luis Fumagallo y Miguel Rodríguez Borges presentaron un proyecto para hacer una plaza de recreo en aquel espacio. Fumagallo había fundado dos años antes la Fonda Teide, uno de los primeros establecimientos hoteleros, justo frente a la futura plaza, en una vivienda que había sido construida por la citada Sociedad Constructora ${ }^{21}$. La reforma debió finalizar en 1887, porque en agosto y a iniciativa de varios vecinos, la plaza se adornó con árboles y el Ayuntamiento acordó la construcción de una pila ${ }^{22}$. Debió ser en torno a 1890 cuando finalmente el Llano de San Sebastián se transformó definitivamente en plaza, pues en mayo de 1892 se nombró director de la misma a Aarón Luis Otazo, "persona competente no sólo por sus conocimientos botánicos, sino también por su reconocido patriotismo", y se le comunicó al jardinero de la plaza que se pusiera a sus órdenes ${ }^{23}$. Como director, Otazo pidió en esas mismas fechas jaulas y peones «para defender de los vientos y ganados los árboles de la plaza y del

19 Souto, Maria Helena y Cardoso de Matos, Ana (2012): «The 19th century World Exhibitions and their photographic memories. Between historicism, exoticism and innovation in architecture», en Quaderns d'Història de l'Enginyeria, vol. XIII. Barcelona: Universitat Politècnica de Catalunya, p. 61. La difusión se hizo mayor conforme iban realizándose las siguientes exposiciones.

20 AMLO, Libro de actas, 14 de agosto de 1867.

${ }^{21}$ Luque Hernández, Antonio (1998): La Orotava, corazón de Tenerife. La Orotava: Ayuntamiento de La Orotava, p. 475.

22 AMLO, Libro de actas, 24 de agosto de 1887, f. 28.

23 AMLO, Libro de actas, 28 de mayo de 1892, sin foliar. Aarón Luis Otazo (1843-1918) era hijo del que fuera alcalde de Arafo en 1846, Vicente José Otazo Ramos. Fue abogado, músico, fundador de la banda de música Numancia, luego llamada Nivaria, director de la Sociedad Filarmónica de La Orotava, juez, profesor y director del colegio Taoro. 
paseo del Calvario", concediéndole 50 pesetas $^{24}$, lo que nos indica que ya había terminado su urbanización y que se habían plantado los árboles, tanto en su interior como en el lado sur, por donde discurría la calle Calvario y donde hasta hace muy poco aún pervivían varios plátanos del Líbano centenarios. Sin embargo, es probable que la fuente no se colocase hasta varios años después, pues no fue hasta mediados de 1894 cuando la corporación agradeció públicamente a Felipe Machado y Benítez de Lugo haber dirigido la construcción de la pila «que se ha levantado al centro del tanque de la plaza Franchi-Alfaro" y también por el arreglo del piso de la calle Carrera $^{25}$. En 1914 comenzaron las obras del edificio más emblemático de su entorno, el colegio de San Isidro, según proyecto del arquitecto Mariano Estanga y financiado por Nicandro González Borges ${ }^{26}$, personaje sobre el que volveremos más adelante.

Otro lugar singular y formado en el siglo XIX es la plaza de San Francisco, ubicada en el emplazamiento que desde el siglo xvi quedó entre el palacio de Bartolomé Benítez de Lugo y el convento franciscano de San Lorenzo. Aunque su aspecto actual se debe al diseño del arquitecto Tomás Machado en los ańos cincuenta del siglo $\mathrm{xx}$, la ocupación del espacio por lo que pretendía ser un frondoso arbolado se remonta a finales del siglo xix y ocurre a la par que la construcción de una fuente pública. La plantación de los árboles que originariamente se encontraban en la plaza se debió a Antonio Lugo y Massieu, quien dedicó buena parte de su vida al arbolado en pos del embellecimiento de su villa natal, y es elogiable que Lugo intentase crear un espacio armonioso, indiscutiblemente agradable, a pesar de las dificultades de la pendiente.

Otras iniciativas orotavenses tuvieron su origen en este siglo, como la arborización de la conocida como plaza del Teatro, un coqueto espacio ajardinado que se concluyó en 1901, año en el que el Ayuntamiento agradeció públicamente a todos los que material e intelectualmente le habían ayudado en su embellecimiento ${ }^{27}$, pero no adquirió su forma actual hasta 1938. Esta plaza, llamada hoy en día Patricio García, en honor de uno de los constructores de la cercana iglesia de la Concepción, es un triángulo desde su origen. La necesidad de abrir aquel espacio al disfrute de los

${ }^{24}$ AMLO, Libro de actas, 17 de diciembre de 1892, sin foliar. En 1894 se libran a favor de Otazo 13,73 pesetas para abono químico para el arbolado.

${ }^{25} \mathrm{La}$ antigua fuente, desparecida incomprensiblemente en los ańos 50 del siglo xx, presentaba un curioso diseño de estilo francés, apreciable en alguna fotografía de principios de siglo. Teniendo en cuenta el gusto de Felipe Machado por los diseños abigarrados y vegetales, tan del gusto de la época, no es extraño que la fuente adquiriese esa forma. Otazo presentó su renuncia como director en 1896, pero siguió siendo responsable de "su conservación y embellecimiento", al menos hasta el año siguiente. AMLO, Libro de actas, 5 de junio de 1896, f. 36v. En enero de 1897 se destituyó como jardinero a Domingo Pérez Escobar, "por dejadez», nombrándose a Miguel Díaz Borges. AMLO, Libro de actas, 15 de enero y 4 de julio de 1897, f. 57.

${ }^{26}$ Sobre la historia de esta institución véase Cullen Salazar, Juan (1999): El Colegio San Isidro de La Orotava (1907-1998). La Orotava: Fundación San Isidro Labrador. La plaza fue diseñada al estilo francés, como podemos ver en algunas fotografías en las que una incipiente vegetación deja ver la distribución geométrica en torno a una fuente central. En una de ellas pueden apreciarse árboles mucho más grandes en el margen sur, lo que puede indicarnos que estos se plantaron bastante antes.

27 AMLO, Libro de actas, 24 de mayo de 1901, f. 45. 
vecinos, pero sobre todo la presencia del teatro Power, debió ser motivo suficiente para entender que debía convertirse en un lugar mucho más agradable, lo que motivó que se pensase rápidamente en arborizarlo. Pero este proceso se entendió conjuntamente con la ocupación de las ruinas del palacio de Celada y en 1895 se abrió una suscripción popular para derribarlo y en su solar construir una plazoleta ${ }^{28}$. A finales de ese año se aprobó la adquisición del solar que ocupaba el palacio "para ensanche de las plazas de la Iglesia y Teatro", en escritura otorgada ante Agustín Delgado García, añadiéndose el derribo de las ruinas del edificio y la explanación del terreno ${ }^{29}$. A comienzos de 1896 se reconocía que las obras de la plaza de la iglesia se habían realizado con donativos particulares y se pidió que se asignaran 1500 pesetas para la obra por las dificultades en la pendiente y las que «presenta para las excavaciones que han de practicarse ya por las especiales condiciones del subsuelo, ya por existir en él los cimientos de un edificio que ha desaparecido ${ }^{30}$. El jardín erigido sobre sus restos es otro interesante ejemplo de planificación urbana y de diseño vegetal y lleva actualmente el nombre de su impulsor, bajo el título de plaza de Casañas. La ocupación del espacio debe ser entendida dentro del intento por urbanizar toda la zona bajo un proyecto mucho más amplio en el que, con el paso del tiempo, se proyectará un interesante nuevo teatro de la mano del arquitecto José Enrique Marrero Regalado, que no tuvo la suerte de ser realizado ${ }^{31}$.

Algo similar sucedió en el Puerto de la Cruz. El primer caso es el de la plaza Víctor Pérez, que lleva el nombre del famoso médico, personaje destacado de la ciudad y que debe ser considerada jardín más que plaza (fig. 3). Inaugurada en 1900, tal y como consta en su delicada verja de entrada, fue siempre un remanso vegetal en una ciudad que por aquellas fechas comenzaba a notar el auge del turismo. Este bellísimo rincón portuense tuvo su origen en el homenaje que la población quiso dedicarle a quien había sido el primer defensor de la mejora de las condiciones higiénicas y de salubridad de sus habitantes. Interesado en la botánica como medio para mejorar la salud, el doctor Víctor Pérez fue constante en la búsqueda de un equilibrio entre las investigaciones científicas y el desarrollo agrícola. Llegó a colaborar en los jardines del Hotel Taoro, de cuya sociedad era accionista, siendo la persona

${ }^{28}$ En 1897 se nombra a Antonio María Casañas encargado de las plazas de la Constitución, Iglesia y Teatro. AMLO, Libro de actas, 4 de julio de 1897, f. 57.

29 AMLO, Libro de actas, 17 de noviembre de 1895, sin foliar.

30 AMLO, Libro de actas, 7 de febrero de 1896, f. 9.

31 Rodríguez Bravo, Jesús y Santos Rodríguez, José Manuel (2018): «Aportaciones a la historia del desaparecido Teatro Power», en Revista de Historia Canaria, n. ${ }^{\circ}$ 200. San Cristóbal de La Laguna: Universidad de La Laguna, pp. 269-284. La forma actual de la plaza Patricio García responde al diseño de Tomás Machado, fechado hacia 1938, pero la reforma del espacio se debió en origen a Diego Álvarez Casanova, encargado de la urbanización; a Domingo Aguilar, responsable de la compra de palmeras; y a Hermann Wildpret, a quien le correspondió el sembrado del césped, todo hacia 1901, cuando ya hay cuentas de estas obras. Rodríguez Álvarez, Josuha et alii (2012): "De templo ilustrado a monumento histórico nacional. Reformas e intervenciones contemporáneas en la parroquia de Nuestra Señora de la Concepción, La Orotava», en XX Coloquio de historia canario-americana, pp. 876-890. Las Palmas de Gran Canaria: Casa de Colón, Cabildo Insular, p. 885. 


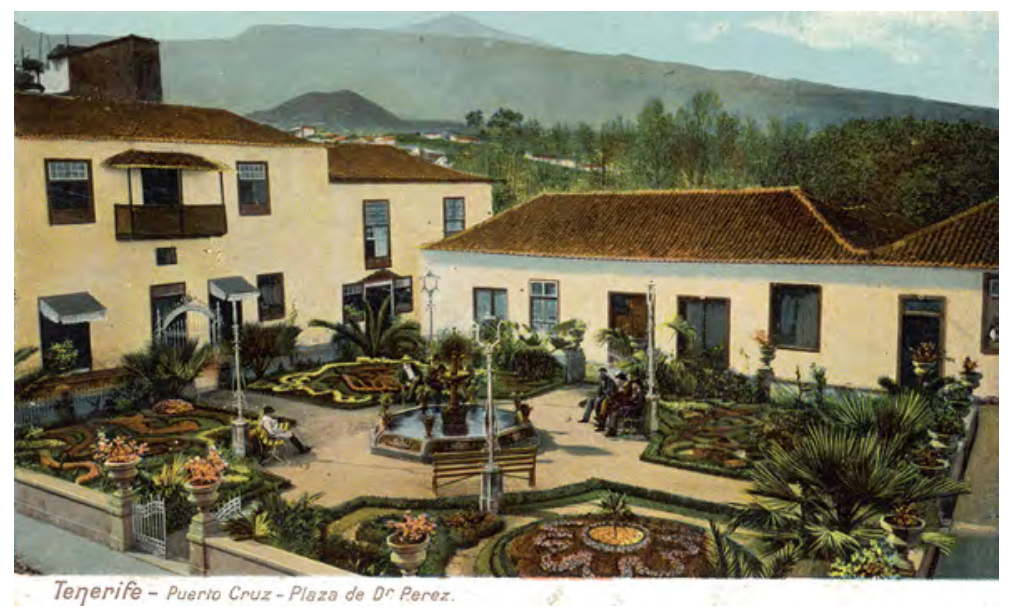

Fig. 3. Tarjeta postal con la plaza de Víctor Pérez, Puerto de la Cruz, c. 1905.

que trajo al arquitecto Adolphe Coquet a Canarias para el diseño del mausoleo de los jardines de la Quinta Roja ${ }^{32}$. La plaza, calificada de "moderna y artística» en su inauguración, se concibió como un rectángulo dividido en cuatro zonas ajardinadas cruzadas por dos caminos perpendiculares y una hermosa fuente central. La vegetación, a modo de parterres, incluía especies canarias, como las altas palmeras que podemos ver en la actualidad. El jardín se cerró con un muro sin verja, de escasa altura y rematado por macetones a lo largo del perímetro. Se le hicieron cuatro accesos, uno en cada lado, donde se colocaron pequeńas verjas, excepto en la entrada principal, en la que se puso una mucho más elaborada que incluyó el nombre del médico y la fecha. En el espacio central, cuatro farolas repetían los modelos decorativos de la reja principal. Formalmente, el cerramiento de la plaza recuerda mucho a las soluciones que desarrollará Estanga para estos espacios.

Esta estructura se aplicó también en otra de las plazas emblemáticas del Puerto de la Cruz. Nos referimos a la plaza de la Iglesia, anteriormente llamada de la pila, cuya antigua estructura era similar al caso anterior, con muro perimetral bajo, rejas y macetones en su cerramiento. La plaza, muy transformada, aún conserva la disposición en parterres de vegetación autóctona con caminos interiores y una fuente central en forma de cisne fechada en 1900. El jardín era un reclamo frente a los hoteles Monopol y Marquesa, situados en su entorno, y fue intensamente fotografiado y difundido a través de antiguas tarjetas postales. Una de ellas nos muestra una perspectiva fantástica de la plaza recién diseñada, con los hoteles

32 Hernández González, Manuel (2005): «Víctor Pérez. Un médico palmero que impulsó la botánica canaria», en Rincones del Atlántico, n. ${ }^{\circ}$ 2. La Orotava: pp. 90-94. Hernández GutiéRrez, A. Sebastián (2009): De la Quinta Roja al Hotel Taoro. Santa Cruz de Tenerife: Ediciones Idea. 
mencionados al fondo y el antiguo convento de Nuestra Señora de las Nieves, San Juan Bautista y Santo Tomás de Aquino a la izquierda. El espacio está delimitado por una verja aún de madera, sin muro de mampostería, y el dibujo trazado por medio de los parterres es de influencia francesa, con la fuente recién inaugurada al centro $^{33}$. Sin duda se trataba de un proyecto relacionado con la búsqueda del embellecimiento de la ciudad, de cara no sólo a sus habitantes sino también al turismo que ya comenzaba a instalarse en aquellos hoteles cercanos. Estos establecimientos también disponían, en algunos casos, de cuidados jardines, como los espléndidos del antiguo Hotel Martiánez o los famosos del Hotel Pino de Oro.

En otros lugares sucedía algo similar. Por ejemplo, desde mediados del siglo XIX ya existían en Santa Cruz de Tenerife dos jardines entendidos como espacios de aclimatación de plantas y lugares de disfrute privado. Por un lado el conocido como Jardín de Salamanca o Jardin de Bellamy y por otro el llamado Jardín de Foronda ${ }^{34}$. El jardín de Salamanca, creado por la familia LeBrun, de origen francés, era un espacio natural racionalizado, es decir, respondía a un diseño estructurado y clásico de jardín en terrazas, culminado por la vivienda principal ${ }^{35}$. Esta disposición venía definiéndose para este espacio desde el siglo XIX, aunque es a partir aproximadamente de 1920 cuando se constata su estructura y elementos ornamentales que lo forman, así como el estilo de la casa principal en torno a la cual se genera el jardín ${ }^{36}$. De esa época es la intervención relacionada con la famosa familia Bellamy, ya que pasa a sus manos en 1914, y de ahí toma el nombre por el que ha sido conocido posteriormente. La prensa de la época recogía entonces las cualidades de las plantas y flores que lo integraban, así como las virtudes de su dueño, Farrow Bellamy, jefe en Tenerife de la conocida compañía Elder Dempster. El gusto de los nuevos propietarios orientó el espacio hacia el cottage garden, más vinculado al uso privado y a la presencia de la naturaleza, tradicionalmente cercano al concepto británico de jardín. Además, se introdujeron elementos arquitectónicos vinculados al gusto por lo inesperado y lo simbólico, como la presencia de una gruta ${ }^{37}$.

El segundo espacio dedicado al cultivo y experimentación de plantas y que también fue muy famoso en su época en Santa Cruz de Tenerife fue el Jardín de Foronda, fundado en 1811 por Francisco Mandillo y Vidal en la esquina de la calle Santa Rita con el entonces paseo de los coches. En 1840 lo continuó cultivando su la FEDAC.

${ }^{33}$ Fotografía de Marcos Baeza, fechada hacia 1900-1905 y conservada en los fondos de

${ }^{34}$ Ambos se aprecian en el plano de la plaza de Santa Cruz de Tenerife levantado en 1856 por ingenieros militares. Rodríguez PeŃA, José Manuel (2016): «Postales de Salamanca. Los jardines de Farrow Siddall Bellamy en Santa Cruz de Tenerife», en XXI Coloquio de historia canario-americana, pp. 1-18. Las Palmas de Gran Canaria: Cabildo Insular.

${ }^{35}$ La compañía LeBrun \& Davidson fue una de las primeras sociedades mercantiles dedicadas al comercio y explotación de cultivos.

36 Con el tiempo la propiedad pasaría de unas manos a otras, instalándose después de 1888 el Sanatorium Salamanca, especie de casa de reposo dirigida por el doctor británico Mordey Douglas. Rodríguez Peña, op. cit.

37 Idem. 
hijo político Juan Manuel de Foronda, de quien tomó el nombre, pasando en 1878 a manos de sus herederos y en 1881 ya lo había adquirido la casa Ghirlanda de la capital tinerfeña ${ }^{38}$. Medía aproximadamente tres fanegadas, distribuidas en una superficie ligeramente inclinada, y en él se habían aclimatado especies de América, Asia y Oceanía gracias al benigno clima de Santa Cruz, sobre todo frutales. Fue de nuevo Hermann Wildpret quien facilitó el catálogo de las plantas a las publicaciones especializadas ${ }^{39}$.

Todos estos lugares públicos que fueron bellamente ajardinados entre los siglos XIX y Xx representan el deseo municipal por crear una ciudad más habitable y acorde con las mentalidades que, como hemos dicho ya, pretendían una relación más cercana del hombre con su entorno. Pero también albergaban otros intereses ligados no tanto al bien común y a la cosa pública como al fomento de la urbanización. Aunque en su defensa, habría que decir que ese concepto aún no tenía las connotaciones negativas que podemos adjudicarle hoy y se entendía como un progreso mucho más equilibrado y de respeto hacia cierto «ornato y decoro».

$\mathrm{Al}$ contrario que estos espacios públicos, los jardines privados eran remansos íntimos, destinados al disfrute personal o familiar, pero también lugares de experimentación paisajista, de investigación científica o de goce estético. Su disposición habitualmente era bastante sencilla, bien en formas geométricas, bien con senderos sinuosos buscando la sorpresa. El diseño podía responder a un capricho del propietario o a una reflexión fruto de investigaciones botánicas pero también a las sugerencias ofrecidas en las publicaciones de la época, como en el caso de la Gaceta Agrícola del Ministerio de Fomento, que en el año 1877 explicaba cómo trazar y componerlos, a lo que denomina «arquitectura de jardines», dando consejos sobre cómo dotar «al paisaje de una gracia y variedad infinitas", cómo situar kioscos en puntos estratégicos o disponer senderos serpenteantes. Los textos eran acompañados con dibujos de exquisitos jardines en perspectivas aéreas, de tal forma que el lector podía inspirarse en su trazado para luego aplicarlo a su jardín privado ${ }^{40}$. Recorrer los ejemplos que existen en el valle de La Orotava de jardines de este tipo significa evidenciar que existió una cultura vegetal de carácter urbano inquieta, culta y hasta cierto punto cosmopolita.

En ese contexto, los Jardines de Franchi representarían el jardín privado por antonomasia. Aunque son fruto de las remodelaciones acometidas desde el siglo XVIII por sus propietarios, los marqueses de El Sauzal, tal vez haya sido el espacio canario ajardinado más difundido fuera de nuestras fronteras, como ejemplo insular de la corriente europea que impulsaba las ideas ilustradas en las mentes y en la

${ }^{38}$ Revista de Canarias, n. ${ }^{\circ}$ 58, 23 de abril de 1881. También en Gaceta Agrícola del Ministerio de Fomento, 1881.

39 Poggi y Borsotto, Felipe Miguel (1881): Guía histórica-descriptiva de Santa Cruz de Tenerife. Santa Cruz de Tenerife: Imprenta Isleña de Francisco C. Hernández, p. 134 y siguientes; Revista de Canarias, n. ${ }^{\circ}$ 58, 23 de abril de 1881; y Gaceta Agricola del Ministerio de Fomento, 1881.

40 Gaceta Agricola del Ministerio de Fomento, 1877. 
arquitectura $^{41}$. La transformación de la casa heredada en el mayorazgo se debe a un interesante personaje, Juan Domingo de Franchi, II de los marqueses y promotor de la renovación paisajística de los jardines de su residencia en La Orotava a partir de $1745^{42}$. La imagen del jardín nos ha llegado a través de dos grabados de Simon Cattoir (1698-1781), al parecer realizados en Lond res a partir de los bocetos del pintor C. de Freudenberg ${ }^{43}$. Aparte de la espléndida vista de los jardines y de la visión de una interesante Orotava setecentista, lo que más llama la atención es la disposición excepcional de algunos elementos del jardín, como los estanques rectangulares, el diseño a la francesa de los distintos ambientes, los laberintos y la regularidad general, muy a la manera de los espacios ajardinados europeos, lo que pone de manifiesto el conocimiento que se tenía de estos a la hora de trazar el de Franchi (fig. 4). El jardín es citado por Ledru, Humboldt o Berthelot, verdaderos expertos y conocedores de otras realidades más allá de las islas. A pesar de la importancia del conjunto y de la trascendencia que la casa y el jardín tuvieron en La Orotava y fuera de ella, a comienzos del siglo XIX se encontraban bastante deteriorados, siendo recuperados hacia 1836 por la VII marquesa ${ }^{44}$. Lamentablemente, buena parte de la construcción y de sus jardines desaparecieron en 1902 debido a un segundo incendio ${ }^{45}$. Fue entonces cuando el arquitecto Mariano Estanga diseñó la singular nueva vivienda que vemos hoy en día, ejemplo ilustrativo de la renovación arquitectónica vivida en las islas a comienzos del siglo xx y en la que convivirán las estéticas modernista, ecléctica y racionalista. El edificio de Estanga no sólo recuperaba la vinculación de la casa con el jardín, sin las dimensiones anteriores, eso sí, sino que también anteponía a la nueva construcción un jardín de entrada, abrazado por los laterales de la casa y que desembocaba en una portada a la que se accedía por una pequeña escalinata. La idea era, de nuevo, que desde el exterior se pudiera ver el espacio ajardinado, gracias a una verja que daba a la calle y desde la que se apreciaba no sólo el jardín, la fuente central y la escalinata, sino también el antiguo escudo familiar en el bello frontón de la portada.

41 Martín López, David (2006): «La casa de Franchy de La Orotava: megalomanía y estética arquitectónica en Canarias (1745-1908)», en XVII Coloquio de historia canario-americana. Las Palmas de Gran Canaria: Casa de Colón, Cabildo Insular, pp. 1352-1362.

${ }^{42}$ La vivienda anterior sufrió un aparatoso incendio la noche del 23 de junio de 1745, en el que se perdieron casi la totalidad de las obras de arte que albergaba. Este será el principal motivo que llevará al marqués a reconstruir por completo la mansión, anexionándole el jardín, bajo un concepto unitario.

${ }^{43}$ Los grabados están firmados por Cattoir y Freudenberg. Martín López, op. cit., p. 1357. A Freudenberg se le ha confundido con el pintor suizo del mismo apellido, llamado Sigmund. Véase Gaviño de Franchy, Carlos (2008): «La estampa en Canarias. Desde los comienzos del reinado de Felipe V hasta la subida al trono de Isabel II", en Historia cultural del arte en Canarias. V El despertar de la cultura en la era contemporánea. Artista y manifestaciones culturales del siglo XIX en Canarias, pp. 247-270. Santa Cruz de Tenerife: Gobierno de Canarias, p. 263.

${ }^{44}$ Martín López, op. cit., p. 1359.

45 Mencionado en El correo español, 11 de enero de 1902; Heraldo de Madrid, 10 de enero de 1902; El País, 11 de enero de 1902; o La correspondencia de España, 12 de enero de 1902. 


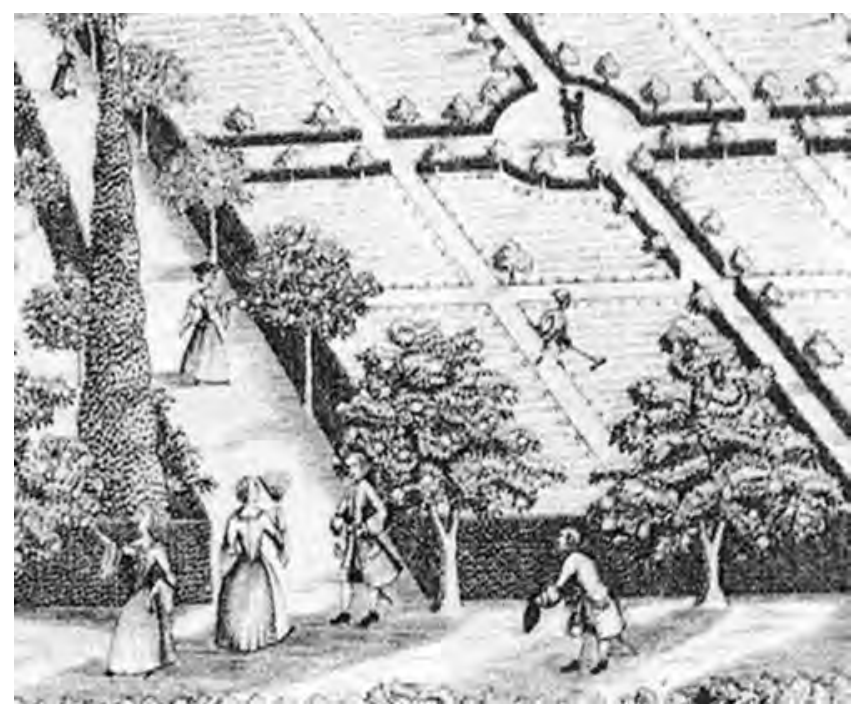

Fig. 4. Detalle de uno de los grabados de los jardines de Franchi.

Muy cerca de los jardines de Franchi se encuentra el que en otros tiempos fuera famoso Jardín del marqués de la Candia, en la trasera de una interesante vivienda conocida como casa de los escalones, perteneciente a la familia Cólogan, de quienes toma nombre la calle. Lo más destacado de este espacio fue su famoso castaño centenario, plantado en unos jardines de tipo privado con caminos interiores y que fue objeto de visita e investigación de muchos de los naturalistas, científicos y curiosos llegados a La Orotava, sobre todo durante los siglos XVIII y XIX, aunque se estimaba que había sido plantado durante la conquista de la isla. Era famoso por su porte corpulento y la abundancia de frutos, hasta doce fanegadas de castańas, y desapareció a mediados del siglo xx tras las secuelas de los fuertes vientos ańos antes ${ }^{46}$. Diego Navarro Soler, en un artículo publicado en 1876, afirmaba que lo había contemplado absorto muchas horas, «como las pasan cuantos viajeros lo visitan, existe en una huerta de nuestro respetable amigo el señor marqués de la Candia, situada dentro de la población de la Orotava. Desprendido de todo aparato de vegetación propia, y hasta de las ramas que elevaban su porte a grande altura, cuando proyectaba su sombra sobre una inmensa superficie, aún conserva cinco gruesas ramas que se considerarían cinco corpulentos troncos de otros seculares castańos si se halla-

46 Hay en La Orotava otro castaño famoso conocido como de las Siete Pernadas y situado en Aguamansa. Su origen se remonta a la misma época que el del marqués de la Candia y, aunque mermado, tiene una circunferencia de más de doce metros y un espeso porte. Ambos han sido históricamente visita obligada en las ascensiones al Teide. 
sen separadas del que a flor de tierra sigue ofreciendo una circunferencia que mide

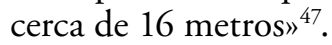

Tanto uno como otro representan la idea de jardín privado por excelencia. Un espacio destinado casi únicamente al disfrute del dueño de la vivienda y de sus familiares y al que tenían acceso sólo aquellas personalidades representativas o científicamente interesadas en su conocimiento o estudio. Ambos eran jardines construidos hacia dentro, alejados de la visión del transeúnte y que pasaban desapercibidos para el gran público. Sin embargo, con la llegada del siglo xix, el nuevo planteamiento urbano en su aspecto vegetal ya no se entendía de la misma manera. Aunque los jardines siguieran teniendo un carácter privado ya no eran tan íntimos, pues se desplazaron a las partes delanteras de las casas, como antesala de las viviendas o como complemento decorativo de la propia construcción. También se transformaron en símbolo del estatus de la familia, sobre todo entre la clase burguesa, que gustaba de mostrarlos. Por esa razón las tapias que en otro tiempo ocultaban la espesura de los mismos se convirtieron en muros con vallas de hierro forjado exquisitamente trabajadas, bajaron su altura y dejaron ver desde el exterior lo que antes era un tesoro interior. Un caso sintomático de este tipo de espacio lo constituye el denominado Jardín Victoria, que no puede entenderse sin la construcción del mausoleo masónico que Sebastiana del Castillo mandó erigir en medio de los jardines de su casa en honor de su hijo Diego Ponte del Castillo ${ }^{48}$. La concepción espacial del conjunto, ideada por el arquitecto francés Adolphe Coquet en 1882 y ejecutada por Nicolás Álvarez y Olivera, en torno al monumento funerario, al que se accedía por una enorme escalinata y que estaba rodeado de vegetación simbólica, no deja de ser un referente en la época, a pesar de las connotaciones sociales y políticas locales ${ }^{49}$. Además, Sebastiana del Castillo era una amante de la botánica y la horticultura y

47 Navarro Soler, Diego (1876): «El castaño gigante de Tenerife», en Almanaque de la Gaceta Agrícola del Ministerio de Fomento para el año 1877.

${ }^{48}$ Para estudiar el origen y las razones de su construcción véanse, entre otros, PAz SÁNchez, Manuel de y Carmona Calero, E. (1996): La masonería. Santa Cruz de Tenerife: Centro de la Cultura Popular Canaria; González Lemus, Nicolás y Rodríguez Maza, José (2004): Masonería e intolerancia religiosa en Canarias, el caso del marquesado de la Quinta Roja. Sevilla: Ediciones Benchomo; Paz SÁnchez, Manuel de (2007): «El jardín de la virtud. La masonería como una disidencia cristiana del siglo XIX", en Anuario de Estudios atlánticos, n. ${ }^{\circ}$ 53, pp. 299-336. Las Palmas de Gran Canaria: Cabildo Insular; Hernández Gutiérrez (2009), op. cit.; o Martín López, David (2010): «Matriarcado arquitectónico y estética masónica: el paradigma de la marquesa de la Quinta Roja», en Revista del departamento de Historia del Arte y Música, n. ${ }^{\circ}$ 0, pp. 66-89. Universidad del País Vasco.

49 Nicolás Álvarez y Olivera desarrolló su labor básicamente en el valle de La Orotava, a caballo entre los dos siglos. Intervino también en el Hotel Taoro, en la construcción del Ayuntamiento y en algunas viviendas particulares de La Orotava, o en las iglesias de Ntra. Sra. de la Peña de Francia del Puerto de la Cruz y la Concepción de Los Realejos. Véanse para estas últimas Fraga GonzÁlez, Carmen (2008): «Edificación de la nueva fachada en la parroquia matriz del Puerto de la Cruz», en Catharum, n. ${ }^{\circ}$ 9. Puerto de la Cruz: Instituto de Estudios Hispánicos de Canarias; y Hernández González, Manuel (2011): "A comienzo del siglo: la construcción de la torre de la parroquia matriz del Realejo Bajo», en Catharum, n. ${ }^{\circ} 11$. Puerto de la Cruz: Instituto de Estudios Hispánicos de Canarias. 
defensora a ultranza del derecho de su hijo a ser enterrado dignamente. Diego Ponte del Castillo, VIII marqués de la Quinta Roja, había fallecido sin descendencia en abril de 1880 y era, como señala Manuel de Paz, un influyente francmasón en el valle de La Orotava ${ }^{50}$. La polémica en torno a su enterramiento, denegado por las autoridades eclesiásticas, llevó a su madre a la construcción del mausoleo y la transformación de las que eran tierras de cultivo en lugar ajardinado y simbólico. El jardín concebido como espacio privado se transformó en lugar común y público, pues el caso del enterramiento se convirtió en asunto de la calle y había que mostrarlo, exhibirlo, como una especie de catarsis social que redimiera el ultraje. Como señala Martín López ${ }^{51}$, desde el primer momento el jardín tuvo cierto carácter público, al poder ser visto desde la cercana plaza de la Constitución, o al menos fue concebido como elemento visible públicamente de un deseo y una lucha familiar por rescatar la memoria de un hijo. Por lo tanto, el espacio fue rápidamente asumido por la sociedad e incorporado a su cotidianeidad, a pesar de su origen íntimo ${ }^{52}$. Cuando Daniel Morris lo visitó en 1895 lo describió como «un bello jardín distribuido en terrazas que contiene gran cantidad de agradables laureles canarios, el bello Lotus Berthelotii y numerosas plantas trepadoras y rosas que adornan las paredes». Con el tiempo la casa de la marquesa de la Quinta Roja fue heredada por Jorge Pérez Ventoso, quien en 1906 la alquiló a Eulogio José Méndez Machado, que la convirtió en el famoso Hotel Victoria, al parecer llamado así en honor de la reina Victoria Eugenia de Battenberg, esposa de Alfonso XIII. Inaugurado en 1907, el establecimiento se convirtió en referente de la villa y sus jardines fueron objetivo de las cámaras, de tal manera que la sociedad de principios del siglo xx gustaba de fotografiarse entre la vegetación y los elementos ornamentales, lo que provocó que el jardín terminase por adoptar la denominación del hotel ${ }^{53}$.

Prolijo sería enumerar otros jardines privados o lugares públicos ajardinados, algunos de ellos citados en publicaciones de la época, como los de las familias Machado o Monteverde, en el que se cultivaban «cuantas novedades botánicas se abren paso en todos los continentes» $\mathrm{o}$ «diversas especies de helechos arbóreos

50 Paz Sánchez (2007), op. cit.

51 Martín López, (2010), op. cit., p. 79.

52 El jardín fue reclamo de turistas desde poco después de su construcción. En 1903 Osbert Ward, autor de la famosa guía de viajes The Vale of Orotava, dice que La Orotava es principalmente visitada por el «jardín de la Marquesa de la Quinta» pero que para verlo «debe obtenerse un permiso del Dr. Pérez en el English Grand Hotel». Véanse Ward, Osbert (1903): The Vale of Orotava. Londres: W.R. Rusell \& Co; y González Lemus, Nicolás (2012): «De los viajeros británicos a Canarias a lo largo de la historia", en Anuario de Estudios Atlánticos, n. ${ }^{\circ}$ 5, pp. 51-104. Las Palmas de Gran Canaria: Casa de Colón, Cabildo Insular.

53 El Hotel Victoria se trasladó poco después a la cercana casa de Llarena y Monteverde, que había sido construida bajo diseńo de Manuel de Oraá. Hace algunos ańos fue abierto de nuevo al público, pero esta vez en la calle Hermano Apolinar, muy cerca de la Hijuela del Botánico, ocupando una antigua casa reformada por Tomás Machado en el siglo xx. Por su parte, el Jardín Victoria fue incomprensiblemente transformado en el siglo xx y rebautizado ampulosamente como Jardines del marquesado de la Quinta Roja, aunque entre la población sigue utilizándose la anterior denominación. 
creciendo al aire libre, sin el menor abrigo", respectivamente ${ }^{54}$; o el famoso Sitio Litre del Puerto de la Cruz, un jardín reformado en 1841 y que sigue conservando parte de la esencia de la familia Smith; o los situados en otros pueblos y ciudades, algunos tan importantes como la Hacienda de los Príncipes o la Rambla de Castro, en Los Realejos, auténticos espacios verdes en simbiosis con la naturaleza circundante.

Estos espacios ajardinados asociados al gusto privado no se dan únicamente en el centro de las ciudades. Al contrario, es probablemente su ámbito circundante el que más directamente se relaciona con los orígenes de los mismos. Y son las haciendas que se situaban en medio de los campos de cultivo las que son transformadas en el siglo XIX en verdaderos laboratorios vegetales y lugares de introducción de especies, al mismo tiempo que ejemplos del desarrollo de una arquitectura vinculada directamente con el jardín, el eclecticismo de influencia inglesa. Al limitado contexto urbano, el amplio campo ofrecía la posibilidad de muchas más libertades estéticas, tanto en la casa como en los jardines, convirtiéndose en lugares de recreo, de descanso y alejamiento de la vida diaria del centro de las poblaciones; algo que está relacionado directamente con el cambio de mentalidad de ese siglo y con la influencia de las numerosas familias extranjeras asentadas en las islas en esas fechas. El valle de La Orotava será muestra de esa experimentación espacial, dándose algunos de los ejemplos arquitectónicos más singulares e interesantes de la isla, asociados en la mayoría de los casos a jardines de influencia británica.

En cualquier caso fue una transmisión que se dio en ambos sentidos, es decir, el espacio verde urbano se vio influido por la naturaleza circundante, pero acotado por la propia conformación de la ciudad. Y a la vez, la reformulación de las haciendas tuvo en el desarrollo de las ciudades un ejemplo a seguir. En ambas, el diseño arquitectónico tomó elementos de uno y otro lado, dando lugar a estilos difíciles de definir, pero que se alimentaban unos de otros. Es el caso del magnífico arquitecto Mariano Estanga, encargado de dar respuesta a las demandas de una sociedad variada en raíces culturales que tan pronto deseaba una casa de claro signo historicista como una clasicista. Como dice Martín López, la comunidad de extranjeros asentada en las islas demandó una arquitectura de fuerte ascendencia victoriana inspirada en las obras del paisajista escocés Jonh Claudius Loudon o los arquitectos ingleses John Nash, Philip Webb, Richard Norman Shaw, Charles Voysey o William Morris, considerados los fundadores del movimiento Arts and Craft en Gran Bretaña ${ }^{55}$. La biografía de estas personalidades cuya formación desafiaba el ámbito cerrado de la arquitectura, abriéndose al campo del diseño industrial, el concepto artesanal de los materiales y la divulgación, está unida a un estilo de vida sencillo, ligado a la naturaleza y de raíces filosóficas. Los diseños llegaban muchas

54 Navarro Soler, op. cit.; Gaceta Agrícola del Ministerio de Fomento, 1878; y GonZÁlez Lemus, Nicolás (2015): «John y Olivia Stone en la Villa de La Orotava», en El Pajar. Cuaderno de etnografía canaria, n. ${ }^{\circ}$ 31, pp. 10-24. Asociación cultural Día de las tradiciones canarias.

55 Véase Martín López, David (2008): «El cambio estético en la sociedad insular a través de la arquitectura hacendada (siglos XIX y xx)», en XVIII Coloquio de historia canario-americana. Las Palmas de Gran Canaria: Casa de Colón, Cabildo Insular. 


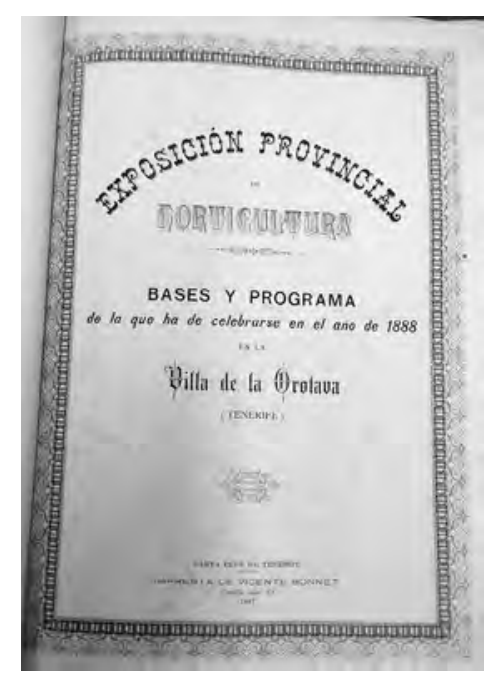

Fig. 5. Portada de las bases editadas en 1887 con motivo de la Exposición Provincial de Horticultura.

veces a las islas a través de curiosos a la vez que interesantísimos catálogos que los arquitectos manejaban para sus creaciones ${ }^{56}$. Estos manuales, conocidos como pattern books, fueron muy populares durante el siglo XIX, convirtiéndose en guías para carpinteros y constructores que incluían técnicas de construcción y detalles de diseño, con alzados y planos que despertaban la curiosidad de la clientela.

\section{LA EXPOSICIÓN DE 1888, LA ARQUITECTURA EFÍMERA Y EL JARDÍN VICTORIA}

El interés por ese nuevo disfrute público definido en la prensa como «la más agradable manera de vivir» se ejemplifica muy bien en esta conocida exposición provincial organizada por el Círculo Agrícola del Valle de La Orotava en 1888. Esta sociedad había sido fundada en 1882 y sus miembros eran destacados personajes ligados a la vida municipal ${ }^{57}$. La exposición fue inaugurada el 20 de mayo de ese año en los jardines de Sebastiana del Castillo, marquesa de la Quinta Roja, en el lugar donde apenas seis años antes se había erigido el mausoleo en honor de su hijo, diseñado, como ya hemos apuntado, por el arquitecto francés Adolphe Coquet en 1882 (fig. 5).

56 Martín López (2008), op. cit., p. 475.

57 Rodríguez Mesa, Manuel (1985): Desde el Falansterio al Liceo de Taoro. Santa Cruz de Tenerife, p. 102. 
La exhibición se había estado gestando desde mucho antes y pudo tener su último impulso en la Fiesta de las flores celebrada en mayo de $1887^{58}$. Pero no podemos olvidar la estela de las numerosas exposiciones celebradas en años anteriores y, tal vez lo más importante, difundidas a través de publicaciones que incluían grabados de las mismas. Es lo que sucedió con las de Londres en 1851 y 1862, las de París en 1855, 1867 y 1878, Viena en 1873 y Filadelfia en 1876. Aunque también se tenían referentes en casos canarios, como la Exposición Provincial de Agricultura, Industria y Artes, celebrada en Las Palmas de Gran Canaria en 1862. Sin embargo, las más divulgadas por estos medios serán algunas de las celebradas en la Península. Como la exposición de agricultura celebrada en Madrid en 1857, para la que se construyó un pabellón específico; la de 1873, celebrada en las cercanías del desaparecido palacio de Indo; o las de flores y plantas de los jardines del Buen Retiro de 1880 y 1883, sobre las que se publicaron grabados en La ilustración española y americana en los que pueden verse distintos pabellones y kioscos ${ }^{59}$.

La antelación con que se gestó la exposición en La Orotava permitió a los organizadores tener delegaciones en varios puntos del archipiélago y prueba la importancia dada al evento, en el que nada se dejó al $\operatorname{azar}^{60}$. A comienzos de agosto de 1887 el presidente del citado Círculo Agrícola, Esteban Salazar, solicitó al Ayuntamiento una subvención para la exposición de horticultura que pensaba inaugurarse en mayo del año siguiente. Tras el informe favorable de los concejales Lucio Díaz y José Gutiérrez, encargados de hacer un presupuesto especial, la ayuda fue concedida apenas una semana después ${ }^{61}$, otorgándole 500 pesetas, que se consideraron suficientes para sufragar los gastos de anuncios, impresos o correo, entre otros, y gracias a ello, en ese mismo año se publicó un folleto con las bases y el programa de la exposición ${ }^{62}$. Con un mes de antelación debían comunicarse los pro-

58 «Al celebrarse en mayo del año próximo pasado en La Orotava (Canarias) la fiesta de las flores surgió la idea de una Exposición de Horticultura en aquel valle de hermosura incomparable». Citado un año después en La ilustración española y americana, 15 de julio de 1888.

59 Volvieron a celebrarse en 1887 y en 1890, momento en el que se hizo la gran exposición de horticultura en el Palacio de Cristal, aprovechando instalaciones de la famosa exposición de Filipinas de 1887.

${ }^{60}$ Tuvo delegaciones en diversos pueblos de la isla e incluso en Las Palmas de Gran Canaria, Arrecife, Santa Cruz de La Palma y Puerto Cabras. Citado en Rodríguez Mesa, op. cit., p. 102.

${ }_{61}$ AMLO, Libro de actas, 11 de agosto de 1887, f. 25v; y 1889 Expediente sobre la Exposición provincial de Horticultura, que se celebrará en esta Orotava, en mayo de 1888.

${ }^{62}$ AMLO, Libro de actas, 24 de agosto de 1887, f. 27v. El folleto fue impreso en la imprenta de Vicente Bonnet de Santa Cruz de Tenerife. AMLO, 1889 Expediente sobre la Exposición provincial... Se imprimió también un programa de actos que incluía un desfile el día anterior a la inauguración, a partir de las 8 de la noche, debiendo estar "convenientemente iluminados todos los edificios de esta población, cuyas calles recorrerá con multitud de antorchas y faroles una banda de música ejecutando el toque de retreta». Al día siguiente, a partir de las 10 de la mańana, habría una romería desde la capilla del Calvario hasta la iglesia de San Agustín con la imagen de san Isidro Labrador y «labradores vestidos al uso del país con largas varas encintadas, niños en romería y dos bandas de música». A continuación habría una función religiosa en la que actuaría la orquesta de El Nuevo Liceo y a las dos de la tarde se inauguraría la exposición. En el mes de agosto el periódico madrileño 
ductos presentados y el espacio que necesitarían para exhibirlos, con el objeto de ser colocados convenientemente. La comisión se encargaba de "procurar la mayor concurrencia de expositores, clasificar artística y ordenadamente los objetos que se encomienden, formar la memoria razonada de la Exposición para conocimiento del público y satisfacción de los interesados». El jurado estaría compuesto por cinco miembros imparciales e inteligentes y los premios consistirían en medallas de oro, plata y bronce, «diplomas de honor, menciones honoríficas y diplomas de buen gusto, fuera de los especiales ofrecidos por corporaciones, sociedades y particulares». El presidente de la comisión era Ubaldo Pimienta y Acosta y los vicepresidentes Antonio Monteverde y Hermann Wildpret; actuando de secretarios Vicente Martínez de la Peńa y Alberto Cólogan ${ }^{63}$.

Nada más comenzar el año, concretamente el 9 de enero de 1888, se publicó en el Boletin Oficial de Canarias un oficio del gobernador de la provincia haciendo un llamamiento a todos los ayuntamientos para que promoviesen «la concurrencia de expositores» y contribuyesen «á la exposición de plantas y flores que debe celebrarse en La Orotava» " ${ }^{64}$. La comisión siguió trabajando durante esos primeros meses en la organización de la muestra, sin tener del todo claro en qué lugar iba a realizarse. En esas gestiones previas, una de las actuaciones más significativas fue la relativa a los espacios expositivos, diseñados a modo de kioscos ricamente decorados. En marzo, Nicandro González Borges pidió que se le concedieran veinte jubrones de pino "para construir kioscos con destino a instalaciones de plantas u otros productos, objeto de dicha Exposición, por carecer de fondos», petición que fue rápidamente concedida ${ }^{65}$.

La Iberia publicó el anuncio de la exposición «que promete ser muy notable». Véase La Iberia, 14 de agosto de 1887. En estas bases se especificaba que podían presentarse a concurso toda clase de plantas, flores, hortalizas y frutos, además de objetos y animales relacionados con la temática de la exposición; que estaría abierta desde la víspera de las fiestas de San Isidro, hasta el jueves siguiente al Corpus; que la flor cortada podía venderse a diario pero otros elementos debían quedarse hasta el final de la exposición; y que todas las plantas y objetos tenían que llevar un rótulo explicativo.

${ }^{63}$ Vicente Martínez de la Peńa (1855-1894) fue notario y abogado, secretario del efímero Círculo Instructivo, fundado en La Orotava en 1881, escritor y presidente del Liceo de Taoro. Como tesorero actuó Ignacio Llarena y Monteverde; y como vocales Tomás Zerolo, Fernando Fuentes, Antonio Llarena, Cándido Acosta, Juan González, José Lugo y García, Enrique Ascanio, Lorenzo Machado y Bernardo Cólogan.

${ }_{64}$ Boletín Oficial de la Provincia de Canarias, 9 de enero de 1888, p. 2.

${ }^{65}$ AMLO, Libro de actas, 11 de marzo de 1888, f. 14. En carta al Ayuntamiento expone lo siguiente: «Dn. Nicandro González Borges, vecino de esta Villa, mayor de edad, soltero y propietario... expone: que para la construcción de kioscos con destino a las instalaciones de las plantas y productos que han de exhibirse en la Exposición provincial de Horticultura que se celebrará en esta Villa en Mayo próximo, necesita la Comisión veinte jubrones de pino; pero como su extracción de estos montes ocasiona gastos a la misma y los fondos de los que puede disponer son tan exiguos que apenas alcanzan para las obras de más imprescindible necesidad que hay que ejecutar, se hace preciso que este Ayuntamiento... [se haga cargo]... de dicha madera con solo el abono por parte del exponente del 10\% que el Municipio paga al Estado para el aprovechamiento de toda clase de efectos forestales; y en tal virtud Suplica a V.I. [...] se digne acordarse expida licencia al que habla para la extracción de los referidos veinte latones, previo pago de una peseta que importa el 10 por 100 expresado 
El 23 de abril el presidente volvió a solicitar la ampliación de la subvención, ya que los gastos habían superado el presupuesto inicial. La corporación, por su parte, se comprometió a velar por la seguridad del evento, dadas las dimensiones que parecía ir adquiriendo, y el 17 de mayo el alcalde solicitó cinco parejas de guardias provinciales para guardar orden en los festejos ${ }^{66}$. Una semana antes, el alcalde Fernando Monteverde publicó un bando en el que recordaba los sacrificios hechos por la comisión y los visitantes que se esperaban, exhortando a los vecinos a recibirlos «con ansia y júbilo». Animaba también a embellecer la población «colgando cortinas de diversas clases y colores e izando vistosas banderas en todas sus azoteas, iluminando los edificios públicos y casas particulares» y esperando que todos secundaran ese propósito ${ }^{67}$. A todo ello se unió que finalmente Sebastiana del Castillo cediera los jardines de su casa para celebrarla.

Tras más de un año de preparación la exposición fue inaugurada el domingo 20 de mayo de 1888 a las dos de la tarde. Para la ocasión se instaló un dosel a los pies de la escalinata del mausoleo para la comisión, bajo el que Tomás Zerolo dio un discurso en el que se refirió a la exposición universal de Barcelona, inaugurada apenas un mes antes. El doctor Zerolo apeló a las ideas fundamentales sobre las que se asentaba aquella nueva visión de la relación del hombre con su entorno como el inicio de una nueva era, diciendo que "se acortan las distancias, se borran las fronteras, se explora el polo, se rompen los continentes, se horadan los montes; sube el globo vencedor y baja el rayo vencido" ${ }^{68}$. Estaban allí el alcalde accidental, Francisco Casanova Hernández, los alcaldes de Santa Cruz y La Laguna, otras autoridades locales, militares y eclesiásticas de la provincia, representantes del cuerpo consular y presidentes de sociedades científicas, literarias, económicas y de recreo. También los directores de establecimientos públicos docentes, la prensa, presidentes de las subcomisiones organizadoras y delegados de las comisiones de otros pueblos. Luego se elevaron «multitud de globos y cohetes», las campanas se hicieron oír y varias bandas de música recorrieron «la población convenientemente engalanada» ${ }^{69}$.

pues... redundará en pró del patriotismo de la I. Corporación. Orotava marzo 3 de 1888». AMLO, 1889 Expediente sobre la Exposición provincial... concejales.

${ }^{66}$ El 10 de mayo, Ubaldo Pimienta invitó por carta a la inauguración al alcalde y a los

${ }^{67}$ AMLO, 1889 Expediente sobre la Exposición provincial...

${ }^{68}$ Las Canarias, 23 de mayo de 1888. La noticia de la inauguración también apareció en los periódicos de Madrid, como El Día y La Unión Católica del 29 de mayo; La República del 30 de mayo; el Diario oficial de avisos de Madrid, del 31 de mayo; o La Ilustración española y americana, del 15 de julio de 1888 .

${ }_{69}$ Estaba previsto igualmente que a partir de las 6 de la tarde la procesión hiciera el recorrido de regreso por la calle Calvario «exornada con elegantes arcos triunfales y banderas» y a las 8 de la noche habría un "paseo en la Alameda de la Constitución» que se hallaría «iluminada a la veneciana» con fuegos artificiales en la plaza de San Sebastián. Al día siguiente habría una exposición de ganado en la plaza frente al Ayuntamiento, se abriría de nuevo la exposición y a las cuatro de la tarde se elevaría «un globo monstruo haciendo su ascensión un aeronauta muy conocido del público orotavense». Y en los días posteriores habría concursos para niños, carreras de sortijas y de nuevo paseos en la Alameda. Así hasta el día 7 de junio en que sería clausurada, coincidiendo con 


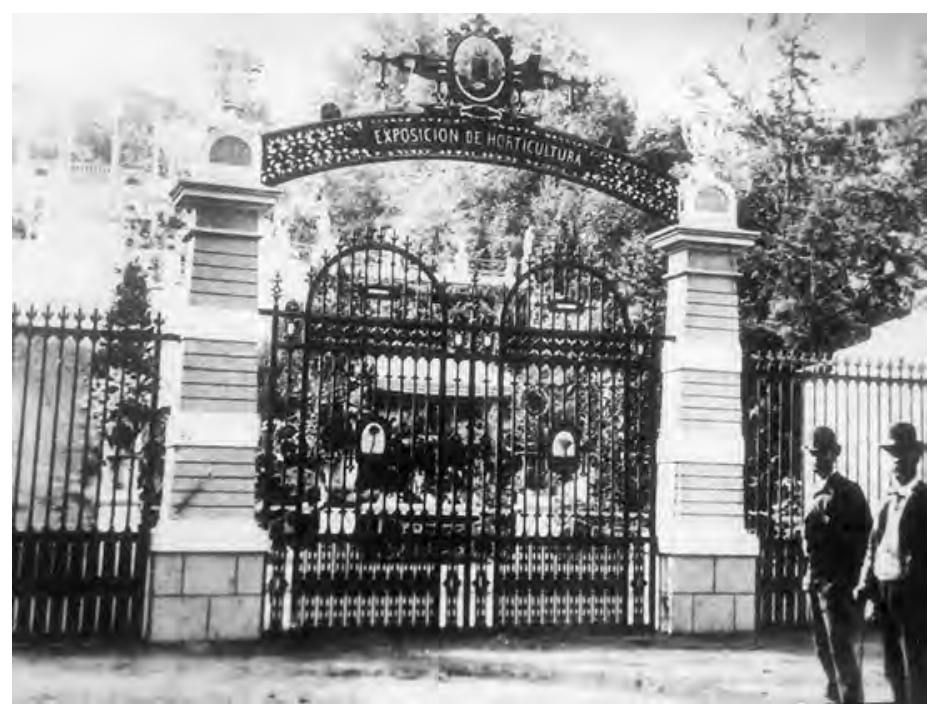

Fig. 6. Acceso a la exposición desde la plaza de la Constitución.

La muestra sirvió de marco excepcional para la arquitectura efímera. A ella se accedía desde dos entradas, una en la calle León y otra junto a la plaza de la Constitución, a través de una rampa y una escalinata diseñada para la ocasión por el citado Nicandro González Borges. La entrada principal era la situada en la plaza y en ella se colocó una bella portada flanqueada por dos pilares rematados por sendos jarrones y una verja con el título Exposición de Horticultura, diseñada por Felipe Machado y Benítez de Lugo y en la que podían admirarse una palmera y un drago ${ }^{70}$. Estaba inspirada en los arcos de entrada de las recientes exposiciones universales y una vez traspasada, un paseo con pequeños lagos y cascadas daba acceso a una rampa que comunicaba con el jardín y que estaba presidida por un gran kiosco de madera para la música (fig. 6). La muestra se estructuraba en extensos parterres, amplias rampas y elegantes kioscos para ciertas instalaciones privadas. Estaba dividida en cuatro secciones: plantas útiles y de adorno; flores y ramos; frutas, legumbres, horta-

las alfombras de flores y terminando con una velada literario-musical en la que se entregarían los premios. Se aclaraba en el programa que algunas noches actuaría en el Teatro Power el septimio de ópera italiana que actuaba en la sociedad Santa Cecilia de Santa Cruz, que en el casino habría un baile de etiqueta y que se estaban haciendo gestiones para que la Alameda fuese iluminada con luz eléctrica. AMLO, 1889 Expediente sobre la Exposición provincial...

${ }^{70}$ La verja fue calificada como una "obra de renacimiento alemán de exquisito gusto. A la derecha y en el fondo nos sorprendió la cascada de doble caída en la que multitud de arbustos, helechos, y plantas acuáticas, coronaban las rocas y piedras que limitaban el cuadro». Las Canarias, 23 de mayo de 1888 . 
lizas y tubérculos; y pájaros y aves vivas y disecadas ${ }^{71}$. Además, se especificaba que podía tener cabida cualquier objeto que "por su belleza o utilidad, pueda figurar en él dignamente, como mobiliario de jardines, macetas modelo, peceras, etc.».

La exposición fue un éxito, con participación de todo el archipiélago y una asistencia, en su inauguración, calculada en 10000 personas por algún periódico. El jurado estuvo formado por Eduardo Rodríguez Núñez, Hermann Wildpret, Saturio Fuentes e Ignacio Llarena Monteverde ${ }^{72}$. La medalla de oro de la comisión fue para la marquesa de la Quinta Roja «por sus jardines y magníficos ejemplares de piteras y laureles de Canarias»; la medalla de oro de la Real Sociedad Económica de Amigos del País de Tenerife fue a parar a Emilio Schönauer, hijo político de Wildprett, con una colección de palmas. El Liceo de Taoro colaboró otorgando un premio a la memoria sobre la crisis agrícola y otro de poesía que ganó Antonio Zerolo y promovió una fiesta escolar con quinientos niños en el recinto de la exposición ${ }^{73}$.

La prensa calificó el certamen como «un acontecimiento que honra a todos y cada uno de los hijos del incomparable Valle y que tardará mucho tiempo en borrarse de la imaginación $»^{74}$. Aunque la mayor aportación fue la de entender que la sociedad demandaba relacionarse de otra manera con la naturaleza. La semilla de este tipo de eventos tuvo otros frutos. Y así, en 1894 la Real Sociedad Económica de Tenerife solicitó al Ayuntamiento orotavense su participación en la Exposición de Agricultura, Industria y Bellas Artes que se celebraría en mayo en la capital en conmemoración de su fundación. La corporación aprobó formar una comisión para «la

${ }^{71}$ La primera sección sobre plantas medicinales, alimenticias e industriales, de adorno, silvestres, colecciones de árboles frutales, maderables y de adorno; la segunda sobre colecciones de flores cortadas, ramos y coronas de flores naturales, ramos y coronas de flores y plantas secas, jardineras adornadas con flores y plantas, modelos de alfombras y tapices de flores y hojas; la tercera sobre frutas, legumbres, hortalizas, tubérculos; y la cuarta sobre pájaros y aves vivas y disecadas.

${ }_{72}$ Sobre Wildprett hubo cierta polémica. Véase Rodríguez Mesa, op. cit.

${ }^{73}$ Idem; y El Valle La Orotava, 6 de julio de 1888.

${ }^{74}$ Las Canarias, 23 de mayo de 1888. El 15 de julio de 1888 la prestigiosa revista La ilustración española y americana publicaba una reseña de la exposición acompañada de un grabado en el que se apreciaban distintas vistas de la misma y que había sido escrita por Eusebio Martínez de Velasco, uno de los redactores de la revista. El cronista lo refiere de esta manera: «El recinto de la Exposición han sido los hermosos jardines de la Sra. Marquesa de la Quinta Roja, que son la perla de la Orotava, y constituyen ellos solos variadísimo concurso de plantas y flores; sobre la alameda de la Constitución se abría una elegante puerta de estilo Renacimiento alemán, bien concebida y hábilmente ejecutada, y en entrando por ella comenzaban las impresiones y las sorpresas; formaba el ingreso de la Exposición una pequeña terraza [...] a la izquierda, bordeando el lago y las cascadas, subía una rampa de pendiente suave, a cuyo término se desarrollaba amplia escalinata rematada por gracioso kiosco; un caprichoso puente rústico se dibujaba sobre la verde arboleda del jardín, de cuyas copas surgían, recortándose en el azul del cielo, algunas de las instalaciones de la Exposición, y allá en el fondo se destacaba, severo y majestuoso, el rico mausoleo [...] parterres, laberintos de follaje, fuentes, estatuas, glorietas, escalinatas de mármol [...] el Catálogo consta de más de 7000 números (plantas, semillas, frutas, colecciones de aves, maderas, muestras de industrias y labores hortícolas, máquinas, etc), y en el concurso han figurado más de 6000 tiestos y macetas de flores, algunas de éstas rarísimas y de elevado precio». La ilustración española y americana, 15 de julio de 1888 . 
conveniencia de expositorio ${ }^{75}$. En abril de 1892 tuvo lugar en Las Palmas de Gran Canaria la llamada Fiesta de las flores, una exposición de carácter regional de plantas, frutos, aves, productos agrícolas, industriales y artísticos para conmemorar los 409 años transcurridos desde la anexión de Gran Canaria a la corona de Castilla ${ }^{76}$. Celebrada en la alameda de Santa Clara y las plazas de San Francisco y Cairasco, incluyó entre sus atractivos diversos kioscos de tipo oriental similares a los orotavenses pero de carácter más efímero. Y a mediados de 1901 volverá a celebrarse una nueva Exposición provincial de floricultura, horticultura y ganadería patrocinada por el Ayuntamiento, la Cámara Agrícola y la Sociedad protectora de animales y plantas útiles de La Orotava ${ }^{77}$. Según las bases, muy parecidas a las de 1888, debía celebrarse en los salones y galerías de las Casas Consistoriales, excepto la ganadería. En aquella ocasión la junta organizadora estaba presidida por Ignacio Llarena Monteverde, actuando como vicepresidente Hermann Wildprett, como vocales Juan Cullen, Francisco de Ponte, Luis Monteverde y Gonzalo Díaz Flores y como secretario Diego de Ponte. Finalmente la muestra fue organizada de nuevo en los jardines de la Quinta Roja.

La exposición marcó un antes y un después en la concepción del espacio urbano como ámbito de lo vegetal y se concibió en unión de otras zonas del centro de la población. Primeramente con los propios jardines de la marquesa de la Quinta Roja, que ya eran de por sí un lugar emblemático y que a partir de esa fecha se transformarían en icono público de las actividades al aire libre, aspecto que perdurará en el tiempo, salvo algunos períodos de abandono. En segundo lugar con la plaza de la Constitución, erigida no sólo en lugar principal de entrada a la muestra, sino también en prolongación de la misma, pues los festejos que se asociaban al certamen se realizaban en este espacio urbano que desde muy antiguo se utilizaba como lugar de los actos más señalados, ya que aún no existía como tal la plaza del Ayuntamiento. La alameda era la antesala de la muestra y su arboleda un elemento más de la conformación del entorno cuando aún no existía el edificio que sería sede posteriormente del Liceo de Taoro; de hecho, el certamen ocupó parte de esa zona. En tercer y último lugar, pero no menos importante, estaba la Hijuela del Botánico, como punto final de la exposición, pues se ubicaba frente a la entrada por la calle León, a modo de continuación visual de los jardines de la marquesa. En ese año ya existía este jardín, diseñado pocos meses antes, pero aún era un espacio con plantas de bajo porte y sin un perímetro claramente vallado, lo que acentuaba más si cabe ese sentido de unión con los jardines de la Quinta Roja. Entre las tres áreas formaban un extenso manto vegetal que ocupaba el centro urbano. Y lo que es más sig-

75 AMLO, Libro de actas, 7 de marzo de 1894, f. 28.

${ }^{76}$ Véase Morales y Martínez de Escobar, Prudencio (1892): Fiesta de las flores. Memoria. Gran Canaria.

77 Se celebró del 13 al 30 de junio de ese año. Puede consultarse el programa de la exposición en la Biblioteca de la Universidad de La Laguna, signatura RCAN 59_65. También en Diario de Tenerife, 1 de febrero de 1901. La Cámara Agrícola había sido oficialmente constituida en ese año. 
nificativo, establecían los lugares de tránsito, intercambio y disfrute de una población que exigía su existencia.

\section{DEL JARDÍN VICTORIA AL HOTEL TAORO}

Debemos pensar que la exposición de 1888 constituyó todo un hito en este tipo de muestras; sin embargo, las previsiones económicas no fueron al final tan halagüeñas como presagiaba el primer día de apertura o al menos eso se desprende de la documentación posterior. En el mes de julio Ubaldo Pimienta, como presidente de la comisión organizadora, señaló ante el Ayuntamiento que no hubo la concurrencia que se esperaba y que los ingresos presupuestados sufrieron una «baja considerable», con un déficit de 1700 pesetas, y que para cubrir los gastos se había decidido subastar los kioscos y enseres, que valían 3740 pesetas. Pimienta indicó por carta que antes de desbaratar aquellas obras tan estimables se las ofrecía a la corporación solamente por las 1700 pesetas, estimación que fue aprobada a condición de que se pudiera hacer en tres plazos y que mientras tanto se depositaran en los bajos del exconvento dominico ${ }^{78}$. Casi un año después, en mayo de 1889 , se designó al creador de aquellos kioscos, Nicandro González Borges, al que se definía como "entusiasta de la cosa pública», para que se encargara de conservar en los bajos del exconvento todos los enseres de adorno del Ayuntamiento y que se usaban habitualmente en las festividades públicas ${ }^{79}$.

La situación económica municipal hará prolongarse en el tiempo el pago de los plazos fijados y a finales de 1889 Ubaldo Pimienta volvió a solicitar que se le abonara el primer plazo de la adquisición de los kioscos ${ }^{80}$. Aun así, en febrero de 1890 se informa que se pagará a los responsables de la exposición cuando se levante la suspensión de intervención de fondos ${ }^{81}$. Finalmente, en junio de 1891 se acordó enajenar el «kiosco de cúpula redonda y el más pequeño, por las setecientas pesetas que por ellos ofrece el alcalde de la capital de esta provincia» ${ }^{82}$. Y en julio de 1892 el gerente de la compañía Taoro de Hoteles y Sanatorium del Valle ofreció por los tres kioscos 1300 pesetas, 200 menos que lo inicialmente estimado, pero acordaron vendérselos para poder saldar la deuda ${ }^{83}$. A Ubaldo Pimienta le hacen entrega de las 1300 pesetas, pero debiéndole aún $400^{84}$. Por suerte para él, en septiembre de

78 AMLO, Libro de actas, 23 de julio de 1888, f. 33v.

79 AMLO, Libro de actas, 11 de mayo de 1889, sin foliar.

${ }^{80}$ Se aprueba la solicitud. AMLO, Libro de actas, 7 de diciembre de 1889, sin foliar.

${ }^{81}$ AMLO, Libro de actas, 23 de febrero de 1890, f. 14. En abril de 1891 se reclaman de nuevo las 1700 pesetas más intereses pero se acuerda no pagar estos, ya que ha sido por tener suspendidos los fondos. AMLO, Libro de actas, 8 de abril de 1891, f. 15.

${ }^{82}$ AMLO, Libro de actas, 17 de junio de 1891, f. $24 \mathrm{v}$.

${ }^{83}$ AMLO, Libro de actas, 21 de julio de 1892, sin foliar.

${ }^{84}$ AMLO, Libro de actas, 13 de agosto de 1892, sin foliar. 
1892 la diputación otorgó una subvención de 1000 pesetas al Ayuntamiento por la exposición de horticultura, de tal forma que se saldó la deuda cuatro ańos después ${ }^{85}$.

De todos los jardines periféricos del valle de La Orotava, tal vez sea el del Hotel Taoro el más difundido internacionalmente, debido a la profusión de postales desde finales del siglo XIX, pero sobre todo en las primeras décadas del xx. En marzo de 1884 Nicolás Benítez de Lugo solicitó ayuda al Ayuntamiento de La Orotava para desarrollar la construcción de hoteles en los Llanos de la Paz para habitación de enfermos de vías respiratorias. El proyecto contó con la aprobación del subdelegado de medicina del partido y los médicos de la villa, Tomás Zerolo y Alonso Perdigón. Estos consideraban que era un proyecto beneficioso y solicitaron que se declarara de utilidad pública y estuviera libre de contribución durante quince años, aunque la propuesta fue finalmente desestimada ${ }^{86}$. No obstante, la historia de estos jardines está ligada a la fundación en 1886 de la Compañía de Hoteles y Sanatorium del Valle de La Orotava, formada por miembros de la aristocracia y la burguesía que comenzaron a ver una salida a la maltrecha economía insular, víctima de la crisis de la cochinilla, en la llegada de turistas europeos y el adecuado clima para mejorar su salud ${ }^{87}$. Como dice González Lemus, esta incipiente infraestructura generó una intensa actividad en el valle, que demandaba productos relacionados, como los constructivos o los bienes muebles y alimenticios ${ }^{88}$. Pero también mejoras en infraestructuras comunes o la participación en actos enfocados en la misma línea como la ya mencionada Exposición de Horticultura. En ese sentido, en 1888 la compañía Taoro decidió construir un hotel en la zona conocida como Monte Miseria ${ }^{89}$ y encargar el proyecto a Adolph Coquet, conocido por haber diseñado el mausoleo de la Quinta Roja. Las obras se prolongaron hasta 1890 en su parte central, inaugurada ese año, bajo la supervisión del arquitecto Manuel de Cámara, iniciándose las alas laterales del edificio en 1891 a cargo de Nicolás Álvarez, famoso contratista de La Orotava, y terminadas en 1893. El Taoro Grand Hotel era una gran atalaya desde donde poder contemplar el Puerto de la Cruz, pero también las laderas de las montañas y el Teide. Precisamente hacia esta parte se extendió el jardín, con alamedas y espacios deportivos ${ }^{90}$. Era un hotel confortable, europeo y lujoso; pero sus jardines eran algo más que todo eso. Se conformaban como grandes exten-

${ }^{85}$ Se nombra a Nicolás de Ponte y Urtusáustegui para que recoja esta subvención en la capital, gestión que no hará hasta el 3 de diciembre de ese año. AMLO, Libro de actas, 10 de septiembre de 1892, sin foliar. Aún en 1894 se le pagaron a Dolores Perera 180 pesetas que no se le habían podido abonar antes, en concepto de gastos de la muestra. AMLO, Libro de actas, 11 de julio de 1894, f. 53v.

${ }^{86}$ AMLO, Libro de actas, 6 de marzo de 1883, f. 11.

87 GonzÁlez Lemus, Nicolás (2002): «La compañía de hoteles y Sanatorium del Valle de La Orotava. Primera compañía turística de Canarias», en XV Coloquio de historia canario-americana. Las Palmas de Gran Canaria: Cabildo Insular, pp. 387-397. Hernández Gutiérrez (2009), op. cit.

${ }^{88}$ Favoreciendo la aparición de otros hoteles como el Marquesa o el Monopol. Ibidem, p. 388.

89 Ibidem, p. 389.

90 «Casi detrás del hotel están sus encantadores jardines, en terrazas sobre la ladera lávica de la montańa...». Descrito en Latimer, S. Frances (1888): The english in Canary Isles. Londres: Simpkin, Marshall and Co., p. 27. 


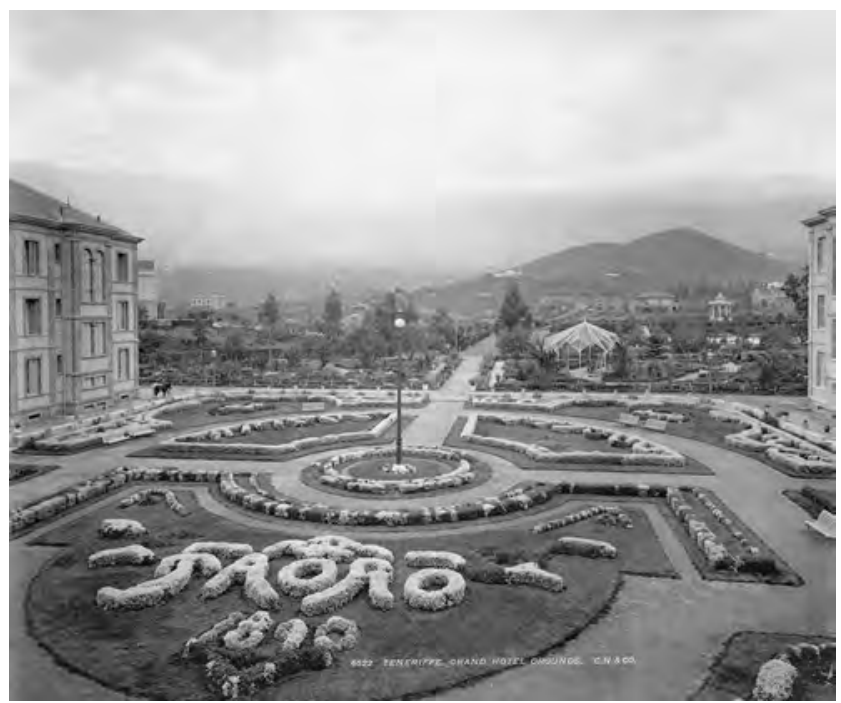

Fig. 7. Jardines del Hotel Taoro. Fotografía de Carl Norman, 1893. En la esquina superior derecha puede apreciarse el kiosco de los coleus ya colocado y detrás la iglesia anglicana.

siones al estilo inglés, es decir, que, traspasada una primera zona ajardinada geométricamente, situada frente al hotel, los visitantes se adentraban en un entramado de lugares que con el tiempo y el crecimiento de la arboleda se transformaron en espacios de sorpresa en los que el malpaís sobre el que se había diseñado se dejaba ver y en los que se podían encontrar los kioscos comprados al Ayuntamiento de La Orotava o la iglesia anglicana de All Saints, levantada en 1890 bajo las líneas del neogótico inglés y perfectamente integrada en los jardines del hotel ${ }^{91}$ (fig. 7).

Esta fuerte presencia de la colonia inglesa se dejará sentir en una edificación muy cercana al Hotel Taoro, la hacienda El Robado, otro ejemplo sintomático de la fuerza de la comunidad extranjera y construida en el Puerto de la Cruz por el coronel británico Owen Peel Wethered en 1893, personaje vinculado también a la construcción de la iglesia anglicana ${ }^{92}$. No vamos a entrar en la historia de este cautivador ejemplo de arquitectura victoriana en el valle, pues ha sido estudiado conve-

${ }^{91}$ Lo resumirá bastante bien un artículo sobre el valle de La Orotava publicado en La ilustración artística, al hablar del Hotel Taoro: «En el patio comprendido entre el cuerpo principal y las alas hay un precioso parterre o jardín inglés, con caprichosos dibujos simétricos que constituyen una alfombra encantadora. Rodean el edificio preciosos jardines, con bosquecillos y glorietas, con pequeńos estanques y con preciosas y fragantes flores que embalsaman el ambiente. En estos jardines, cuidados y atendidos con gran esmero, gusto e inteligencia, crecen hoy unos doce mil árboles». La ilustración artística, 5 de diciembre de 1898.

${ }_{92}$ La colonia inglesa se reunirá el 6 de enero de 1888 en el Jardín de Aclimatación para asistir a un concierto de la sociedad filarmónica de la Villa. Las Canarias, enero de 1888. 
nientemente ${ }^{93}$, pero sí mencionaremos su jardín, actualmente abandonado al igual que la casa ${ }^{94}$. Este espacio que originariamente rodeaba al edificio fue concebido en unión del mismo, ya que se entendía que la naturaleza formaba parte de la construcción. De esta manera los accesos estaban estudiados para que dieran a determinados espacios deportivos o ajardinados. Estos últimos fueron concebidos dentro del paisajismo inglés típico, basado en una aparente falta de orden pero que en el fondo estaba perfectamente estudiado. En 1927 compraron la casa los duques de Peñaranda y pasó a denominarse San Fernando, que es como se conoce actualmente a toda esta zona. La edificación se modificó, perdiendo su apariencia victoriana y adquiriendo formas tradicionales de la arquitectura canaria. Sin embargo, la transformación que más nos interesa fue la del jardín. El diseño al estilo de la campiña inglesa fue sustituido por una estructura geométrica y regular. Este cambio se debió en origen al importante paisajista francés Jean Claude Nicolas Forestier (1861-1930), muy vinculado a la familia Peńaranda ${ }^{95}$. No obstante, la realización del proyecto de Forestier es obra de uno de sus más destacados discípulos, el catalán Nicolau Rubió i Tudurí (1891-1981), verdadero ejecutor de la obra tras la muerte del primero en $1930^{96}$. Rubió acercó el jardín al hombre y a la geometría, distribuyendo regularmente el espacio y ańadiendo trazados a modo de paseos perpendiculares, pero respetando los desniveles del terreno, bajo el concepto de sensibilidad que caracteriza su obra. La vegetación siguió adueñándose del espacio, pero de forma mucho más organizada, y se incluyeron pabellones de cara al disfrute y el ocio tan de moda en el momento.

Como puede suponerse, el caso del Hotel Taoro no es único, aunque sí es el de mayores dimensiones. Como ha estudiado muy bien González Lemus, La Orotava de la segunda mitad del siglo xix es uno de los primeros municipios en los que se establecen albergues, fondas u hoteles para el incipiente turismo, ligado tanto al estudio científico como a la salud ${ }^{97}$. Estos viajeros decimonónicos que aspiraban a subir al Teide y disfrutar del que era considerado uno de los valles más hermosos se alojaron en pequeños hoteles que empezaron a formar parte del tejido urbano y que contribuyeron a embellecerlo y, sobre todo, a mejorar las condiciones de las vivien-

93 Véanse Martín López (2008), op. cit. y Rodríguez Peña, op. cit.

${ }^{4}$ La vivienda ha estado en situación de abandono durante ańos y en 2008 sufrió un aparatoso incendio que destruyó buena parte de su interior. A pesar de ser declarada Bien de Interés Cultural y de que se han hecho inventarios de las plantas que sobreviven aún en su jardín, nada parece evitar su progresivo deterioro.

95 Rodríguez Peña, José Manuel (2013): «De El Robado a San Fernando. Historia de un jardín de Puerto de la Cruz», en Catharum, n. ${ }^{\circ} 13$. Puerto de la Cruz: Instituto de Estudios Hispánicos de Canarias, p. 25.

96 Para ampliar su concepto de jardín véase Cañelas, Celia et al. (1976): "Nicolau M. Rubió i Tudurí, entre la razón y la sensibilidad», en Cuadernos de arquitectura y urbanismo, n. ${ }^{\circ} 13$. Colegio Oficial de Arquitectos de Cataluña y Baleares.

${ }^{97}$ A modo de resumen, resulta clarificador el pregón leído por Nicolás González Lemus con motivo de las fiestas del Corpus en 2014. Véase GonZález Lemus, Nicolás (2014): Pregón de las fiestas del Corpus Christi y San Isidro Labrador, 24 de junio de 2014. La Orotava. En línea. 


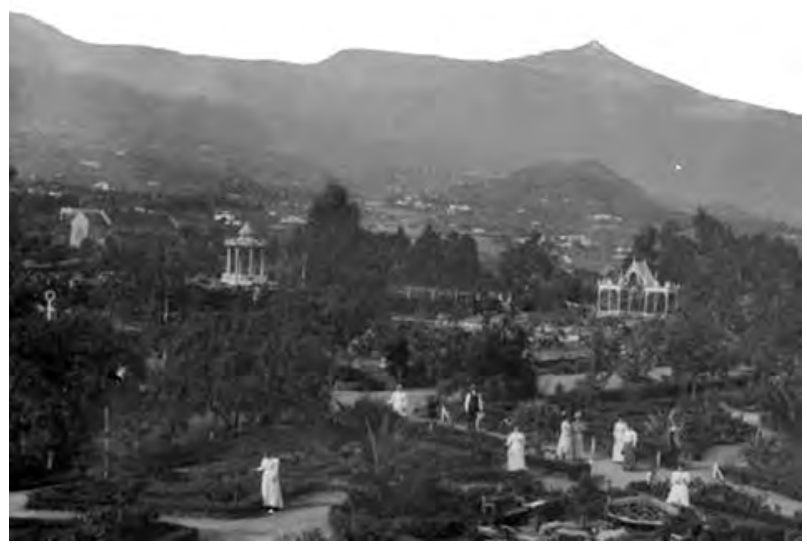

Fig. 8. Jardines del Hotel Taoro. Pueden apreciarse el kiosco de los coleus y el kiosco rectangular de frutos del país.

das en las que se establecían. Casos como los del Hotel Espérides, que anteriormente había sido la Fonda Govea, situado en la casa que había construído Antonio Díaz Flores; el Hotel Teide, del italiano Luis Fumagallo, luego llamado Suizo; la finca El ciprés, alquilada a Douglas Crompton en 1895 como establecimiento hotelero; el Hotel Norte, de Francisco Álvarez; o el distinguido Hotel Victoria a partir de 1906 ponen de manifiesto el interés por una oferta alojativa que estos viajeros se encargaban de difundir, con sus virtudes y sus defectos, a través de los libros de viajes, guías y demás recuerdos plasmados en las numerosas publicaciones aparecidas en la época. Singular es también el caso del Thermal Palace de la costa de Martiánez del Puerto de la Cruz, establecimiento hotelero interesantísimo que era en realidad un pabellón de la Exposición Universal de Bruselas de 1910 y que fue vendido y trasladado a Tenerife pieza a pieza e inaugurado en 1912.

Tras el traslado de los kioscos de la exposición al Hotel Taoro, estos fueron colocados en sus jardines y con el tiempo corrieron distinta suerte. En una fotografía del Hotel fechada en 1890 y conservada en los fondos del Centro de Fotografía Isla de Tenerife y también en la FEDAC, pueden verse tres de ellos situados hacia la parte sur, colocados en sitios estratégicos del jardín: el primero con cúpula oriental en la perpendicular a la entrada del hotel; el segundo, llamado kiosco de los coleus, a la derecha y en medio de la vegetación; y el tercero, único kiosco rectangular, se halla un poco más alejado, también a la derecha ${ }^{98}$. Seguirán apareciendo en otras instantáneas de entre 1892 y 1927, emplazados en el mismo lugar, salvo el kiosco

${ }^{8}$ Centro de Fotografía Isla de Tenerife, ES 38 CFIT-PM-001-000004, ES 38 CFITPM-001-000005 y ES 38 CFIT-PM-001-000012. Podemos ver una preciosa fotografía del kiosco de 


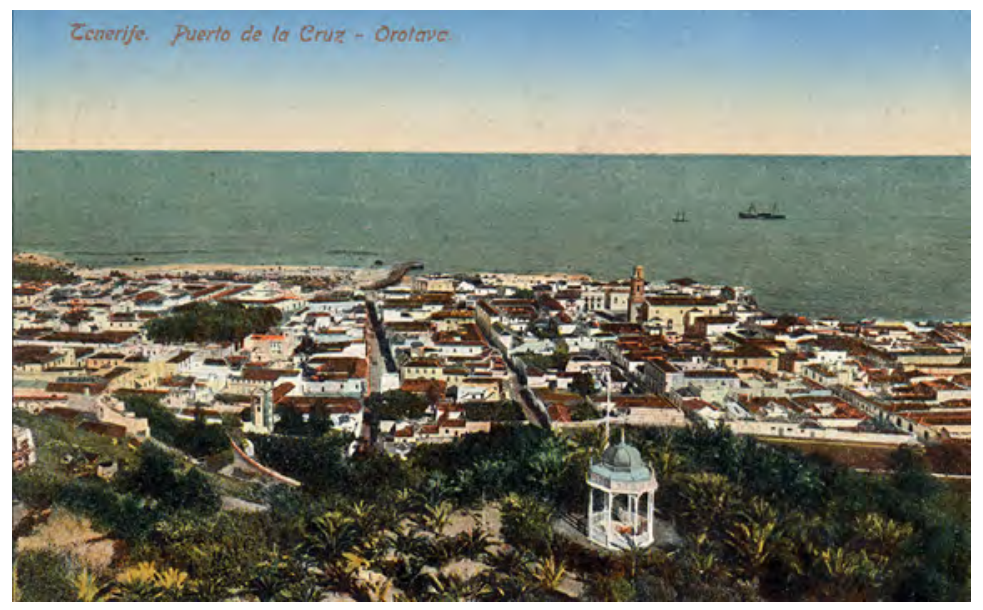

Fig. 9. El kiosco de los helechos ya reubicado, con el Puerto de la Cruz como telón de fondo.

de los helechos, que parece haber sido cambiado de ubicación, ya que nos lo encontramos en la parte norte, con el Puerto de la Cruz como telón de fondo, en fotografías algo posteriores (figs. 8 y 9). Todos ellos debieron desaparecer cuando la zona del Taoro comenzó a urbanizarse y los usos del hotel cambiaron.

\section{EL ARTE EFÍMERO EN EL JARDÍN Y SUS INFLUENCIAS}

En general, las últimas décadas del siglo xix son la edad de oro de la arquitectura efímera ${ }^{99}$. La generalización de este tipo de estructuras se debió, en gran medida, al apogeo de las exposiciones, empezando por las de carácter universal y acabando por las exhibiciones locales o provinciales, como fue el caso de la de 1888 . Los grandes pabellones levantados para la exposición de 1851 en Londres, como el famoso Crystal Palace de Joseph Paxton, se convirtieron en hitos arquitectónicos y referentes para posteriores edificaciones, la mayoría con un carácter eminentemente temporal. Pero no sólo se construyeron estos grandes edificios, sino también otros ejemplos mucho más pequeños, como arcos de triunfo, arcos de acceso, kioscos..., pero siempre influidos por una gran fantasía y con amplias cotas de creatividad. El camino abierto por la capital británica fue rápidamente desarrollado por París,

los coleus en MÉndez Pérez, op. cit. p. 27, en la que se aprecia la influencia de las pagodas orientales en su decoración. Los coleus o coleos se denominan popularmente en Canarias como matasombras.

99 Poblador Muga, María del Pilar (2015): «El ornado de la ciudad y la labor del arquitecto a comienzos del siglo xx: los símbolos y la exaltación de lo vernáculo», en El arte público a través de su documentación gráfica y literaria. Instituto Fernando el católico, p. 274. 
donde se celebraron las mayores exposiciones de los últimos años del Ochocientos, con grandes ejemplos de lo efímero, algunos de los cuales permanecieron, como la torre Eiffel en la de 1889. Lo cierto es que el origen de muchos de estos ejemplos arquitectónicos hay que buscarlo en diversos factores que son decisivos a la hora de entender su apogeo. Por un lado, la influencia y libertad de los diseños desarrollados en los jardines, sobre todo los de influencia inglesa, en los que templetes o "caprichos», como se llamaron en España, llenaron de fantasía los espacios privados y luego se extendieron al ámbito público. Se trataba de una concepción escenográfica del jardín, en la que los espacios y la visibilidad de los mismos eran piezas clave para entenderlo ${ }^{100}$. En segundo lugar, la difusión de la arquitectura oriental, fomentada por las campañas de las grandes potencias, la búsqueda de antiguas civilizaciones o cierta postura romántica asociada al explorador y que tanto influyeron a las vanguardias artísticas finiseculares. En tercer lugar, los medios técnicos, que tuvieron un gran desarrollo gracias a la Revolución Industrial y que permitieron el uso de nuevos materiales, mucho más dúctiles y con grandes posibilidades funcionales, como el hierro o el vidrio. Por último, pero también muy importante, la difusión de imágenes a través de distintas publicaciones de los diseños de jardines, como los fantásticos del paisajista francés Gabriel Thouin, publicados en su tratado en 1820, cuyas láminas de ruinas, fuentes, cenadores... dan idea del grado de imaginación aplicado al embellecimiento del jardín ${ }^{101}$, o de las fotografías y grabados de las mencionadas exposiciones universales. Todas estas circunstancias ayudaron a que la modernidad entrara en los espacios públicos, e incluso en los privados, ya que comenzó a permitirse la entrada a los mismos, para deleite de la nueva sociedad.

El carácter de exaltación que conlleva buena parte de la arquitectura efímera tuvo varios ejemplos en Canarias. En 1866 se levantaron arcos triunfales en Las Palmas con motivo de la festividad del Corpus. Uno de ellos asumió formas historicistas y fue diseñado por Manuel de León y Falcón ${ }^{102}$. Algo similar sucedió con motivo de la llegada del rey Alfonso XIII en 1906, en este caso asociada a figuras clave de este período como el arquitecto Mariano Estanga. Se trataba de obras en las que la libertad de expresión era una muestra más del eclecticismo imperante ${ }^{103}$ (fig. 10). Sin embargo, mucho antes, el escultor Fernando Estévez ya se había encargado de «dirigir las funciones cívicas» que se hicieron al proclamarse la Constitución de 1812, "pintando los arcos triunfales y otras cosas análogas»; o con la subida

100 Prieto González, José Manuel y Rodríguez Romero, Eva J. (1998): «Caprichos en el jardín. Ficción y realidad en la escenografía de los ámbitos de recreo público decimonónicos», en Archivo español de arte, n. ${ }^{\circ}$ 284. Madrid: Consejo Superior de Investigaciones Científicas, p. 397.

101 Ibidem, p. 393.

102 Hernández Socorro, María de los Reyes (1990): «Escenografía urbana y arquitectura efímera en el desarrollo de la festividad de Corpus en Las Palmas a mediados del siglo XIX», en Tebeto, n. ${ }^{\circ}$ 3. Cabildo insular de Fuerteventura, pp. 173-190.

103 Hernández Gutiérrez y González Chávez, op. cit., p. 160 y siguientes. 


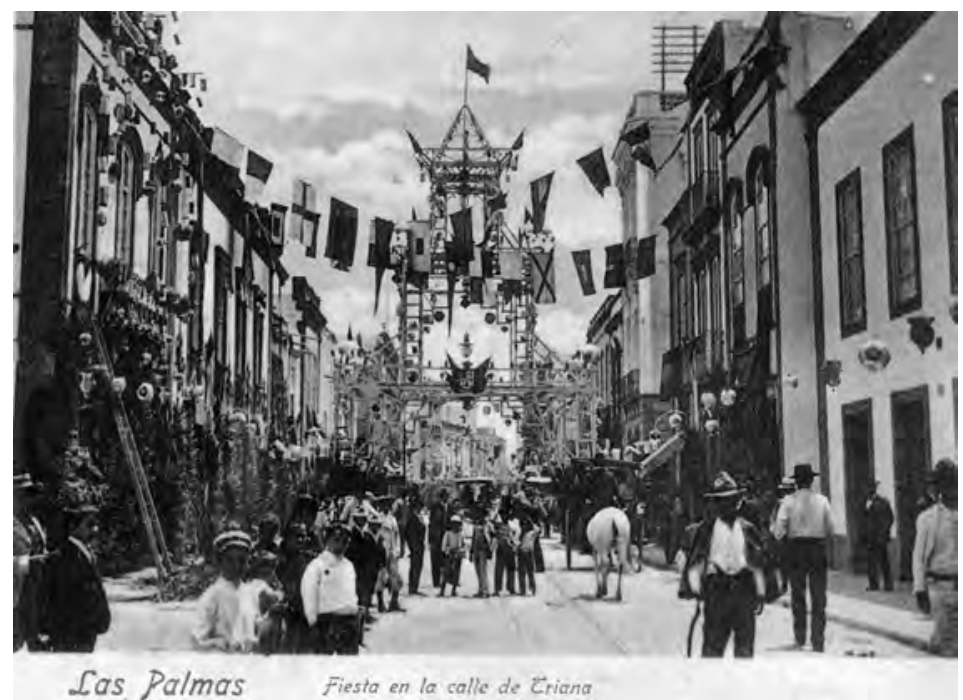

Fig. 10. Arco levantado en la calle Triana de Las Palmas de Gran Canaria, c. 1893.

al trono de la reina Isabel $\mathrm{II}^{104}$. Son manifestaciones tempranas del arte efímero asociado al evento circunstancial.

Casi nada de esto hubiese sucedido sin que se dieran las condiciones económicas necesarias y sin que hubiese personas capaces de respaldarlas y llevarlas a cabo. La mejora económica, aunque transitoria, permitió redefinir los espacios habitados y dotarlos de las necesidades que una sociedad en transformación demandaba ${ }^{105}$.

Es en 1884 cuando el arquitecto Adolphe Coquet describe el estado de La Orotava en su libro Una excursión a las Islas Canarias. Dice el artista que "esta pequeña ciudad, que muestra sus casas blancas, sus miradores, sus cúpulas entre jardines risueños, es La Orotava; lo que se extiende a lo largo de la costa, es el puerto. Aquí está el célebre jardín botánico... La Orotava es una pequeña villa de 8000 habitantes, construida en el centro del Valle. Las calles son muy pronunciadas y las casas se extienden unas sobre otras mirando el mar y su vasto horizonte. Muchos jardines

${ }_{104}$ A su cargo estuvieron de nuevo las que se llevaron a cabo con motivo del regreso al trono de Isabel II. Junto al concejal Clemente Pimienta «fue comisionado para dirigir la función de Yglecia en acción de gracias al todo Poderoso, y también las públicas, habiendo adornado la plaza principal de la Constitución con el mayor gusto". AMLO, Libro de actas, 30 de marzo de 1842, f. 88v y siguientes.

${ }_{105}$ Nada resume mejor lo acontecido en la villa en los últimos cincuenta ańos del siglo XIX que un artículo publicado en el diario republicano La Prensa en 1915. Aunque estemos ya en los inicios del siglo xx, todo lo que refiere el autor del artículo es consecuencia de las actuaciones anteriores y ejemplifica muy bien los cambios a los que se vio sometida la trama urbana, sobre todo en dos aspectos, el nuevo uso de edificios históricos y las ampliaciones viarias. 


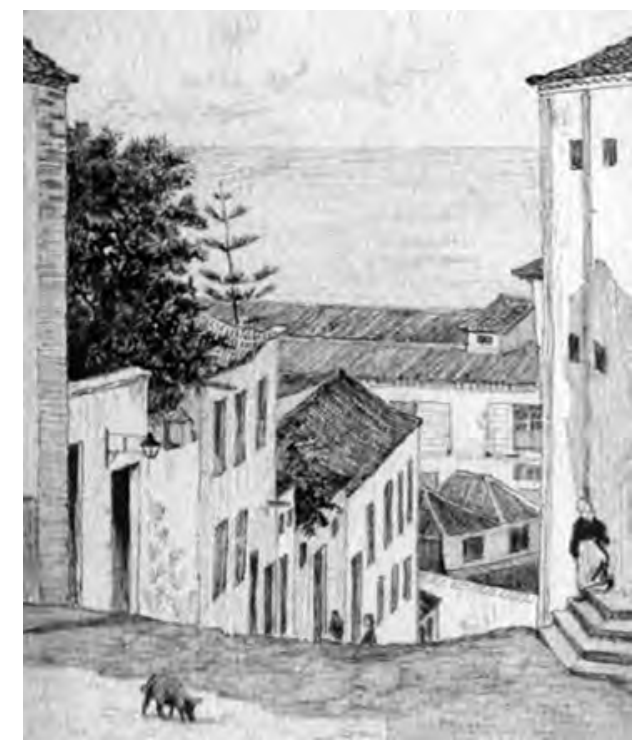

Fig. 11. Dibujo de la calle Cólogan de La Orotava (detalle).

George Derville Rowlandson, 1893. Colección particular, Londres.

superponen sus terrazas todas cubiertas con una gruesa alfombra de vegetación $»^{106}$. Una visión que compartirán otras personalidades llegadas a la isla, bien como simples viajeros, bien con otros fines más concretos (fig. 11).

Como hemos ya señalado, tampoco nada de esto hubiese sucedido sin el trabajo y empeño de diversos personajes, vinculados al embellecimiento de los espacios verdes y, en general, a la mejora del medio habitado. Es el caso del diputado Antonio Domínguez Alfonso, cuyas gestiones en Madrid fueron decisivas para algunos jardines públicos; de Miguel Villalba Hervás, encargado, junto con el anterior, de la financiación del arbolado de la Hijuela del Botánico en 1892 ${ }^{107}$; o de Nicandro González Borges, que plantó en 1909 junto con Juan Pérez Rodríguez, inspector de plazas y paseos, las araucarias de la carretera del Pinito como medida de arbolado en una de las vías de entrada a la población, y cuyas gestiones fueron realiza-

106 Coquet, Adolphe (1884): Une excursion aux Iles Canaries. París: Typographie Georges Chamerot, p. 21 y siguientes.

107 En una carta enviada en febrero de 1892 se alude al patriotismo, iniciativa y empeño de Domínguez Afonso «que parte tan decisiva tuvo en la subvención de la Exposición de Floricultura» y que «apoyó la conversión del Jardín Botánico en una escuela de Floricultura y Jardinería, que pueda convertirse en escuela Agrícola». Publicado en El liberal de Tenerife, 9 de febrero de 1892. La carta fue enviada por Domínguez Afonso a Antonio María Casańas, pero en ella copia fragmentos de la que este le envió a su vez. 
das por Domínguez Afonso en sus años como político en la capital ${ }^{108}$. En esa época también jugará un papel destacado Antonio Lugo y Massieu, editor y director de la revista El Campo, publicada de manera filantrópica en La Orotava entre 1915 y 1931 y cuyos ideales eran el fomento del arbolado, el respeto por la naturaleza y la evolución de la sociedad gracias a ello ${ }^{109}$. Personaje profundamente comprometido con la relación del ser humano con su entorno, fue presidente de la Cámara Agrícola de La Orotava en los años 30 del siglo xx y promotor de la plantación de árboles en carreteras o en la plaza de San Francisco de la villa. El Campo fue su publicación más conocida pero no la única; también fue responsable de La Orotava, La Patria y El Regional ${ }^{110}$. Todas sus ideas sobre la naturaleza las puso en práctica en un jardín de su propiedad, la Quinta Blas Luis, entre 1905 y 1923, en el que experimentó con la distribución o la búsqueda del disfrute y el intercambio social ${ }^{111}$.

De entre todas estas personalidades, sobresale para nuestro estudio la de Nicandro González Borges (1846-1916), cuya trayectoria personal es definitoria de alguien profundamente preocupado por el progreso de su villa natal. Al margen de su vinculación con la exposición de 1888, como ya hemos visto, o de su compromiso con el arbolado de carreteras, tuvo otras significativas iniciativas: en 1892 había plantado los árboles de la calle Castaño, entre los canales de madera de los molinos; en 1911 donó varios bancos de piedra para embellecer la plaza de la Constitución; al año siguiente costeó la construcción del tímpano del ayuntamiento, una de cuyas figuras alegóricas es la agricultura, en colaboración con el arquitecto Mariano Estanga; fue el impulsor de la construcción del colegio San Isidro a partir de 1913, diseñado por el mismo autor; y tuvo un interesante jardín en su finca de Los Orovales, a caballo entre La Orotava y el Puerto de la Cruz, donde experimentó con árboles y plantas de diferentes países ${ }^{112}$. Además, perteneció a distintas sociedades filantrópicas de la época (fig. 12).

No nos extraña, por tanto, que a un personaje tan inquieto como este se deba la creación de los kioscos que debían colocarse durante la exposición de horticultura de 1888 en los jardines de la marquesa de la Quinta Roja. Esta iniciativa supone asumir que González Borges tuvo contacto con los diseños que para los llamados caprichos, «fabriques o folies» en francés, se difundían gracias a revistas como $\mathrm{La}$ ilustración española y americana, en cuyos ejemplares aparecieron entre 1881 y 1888 numerosos grabados en los que podían apreciarse estructuras similares. Es el caso

108 En el mismo paseo y en la misma época se construyeron las primeras ocho viviendas adosadas de promoción social, gracias a la Constructora de Orotava, en una zona escasamente habitada, donde sobresalía, y aún lo hace, la construcción ecléctica conocida como Casa del Chocolate. Véase Méndez Pérez, op. cit.

109 Véase Martín de Lugo, María del Carmen (2003): «Don Antonio Lugo y Massieu: pasión por la naturaleza», en Rincones del Atlántico, n. ${ }^{\circ}$ 1, pp. 24-31. La Orotava, pp. 24-31.

${ }_{110}$ Véase AA. VV. (2005): «Antonio Lugo y Massieu. Una vida entre la naturaleza y la cultura", en Rincones del Atlántico, n. ${ }^{\circ}$ 2, pp. 34-37. La Orotava, pp. 34-37.

111 Véase AA.VV. (2005): "La Quinta Blas Luis: el espíritu de Antonio Lugo y Massieu», en Rincones del Atlántico, n. ${ }^{\circ}$ 2, pp. 162-167. La Orotava, pp. 162-167.

112 Cullen Salazar, op. cit., p. 65 y siguientes. 


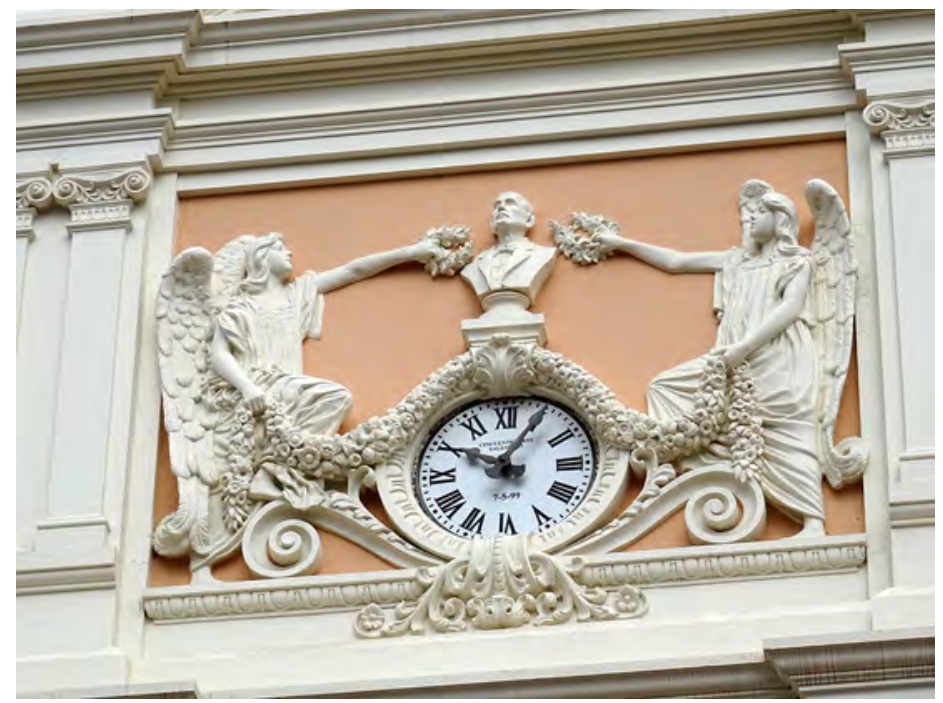

Fig 12. Busto de Nicandro González Borges en la fachada del colegio salesiano San Isidro.

de los años 1881 y 1882, en cuyos números de mayo y junio se mostraban grabados de sendas exposiciones de plantas y animales celebradas en los jardines del Buen Retiro de Madrid ${ }^{113}$. Pero no eran las únicas ocasiones en que se levantaban este tipo de pabellones, aunque con funciones muy diferentes. Por ejemplo, con motivo de la visita de los reyes Alfonso XII y María Cristina a Galicia se muestra un grabado con un kiosco muy similar a los de la exposición canaria, usado como lugar de recibimiento real ${ }^{114}$; o en 1884 se publica un reportaje con ilustraciones de los jardines del palacio de Aranjuez, entre los cuales podemos ver dos kioscos instalados en el jardín del Príncipe que inevitablemente nos recuerdan a los de la exposición de $1888^{115}$. Aunque más evidente es la inspiración en los kioscos que con motivo de la exposición de horticultura celebrada en Valencia en mayo de 1883 se colocaron en esa ciudad ${ }^{116}$; incluso en los pabellones diseñados para la exposición de minerías y artes metalúrgicas, celebrada en Madrid en 1883 y que se publicaron en varios números de esta revista ${ }^{117}$. A comienzos de 1887 se sigue celebrando en el Retiro de Madrid la exposición de plantas auspiciada por la Sociedad Central de Horticul-

113 La ilustración española y americana, n. $^{\circ} \mathrm{xx}$ y xxiv, 30 de mayo y 30 de junio de 1881 ; n. ${ }^{\circ}$ XXI y XXIII, 8 y 22 de junio de 1882 .

${ }^{114}$ La ilustración española y americana, $\mathrm{n} .{ }^{\circ} \mathrm{XxxI}, 22$ de agosto de 1881.

115 La ilustración española y americana, $\mathrm{n} .^{\circ} \mathrm{xv}, 22$ de abril de 1883.

116 La ilustración española y americana, $\mathrm{n} .{ }^{\circ} \mathrm{xx}, 30$ de mayo de 1883 . Volverá a repetirse esa influencia en la cita de 1887. La ilustración española y americana, $\mathrm{n} .^{\circ}$ XxxII, 30 de agosto de 1887.

117 La ilustración española y americana, n. ${ }^{\circ} \mathrm{xxv}, 8$ de julio de 1883. 


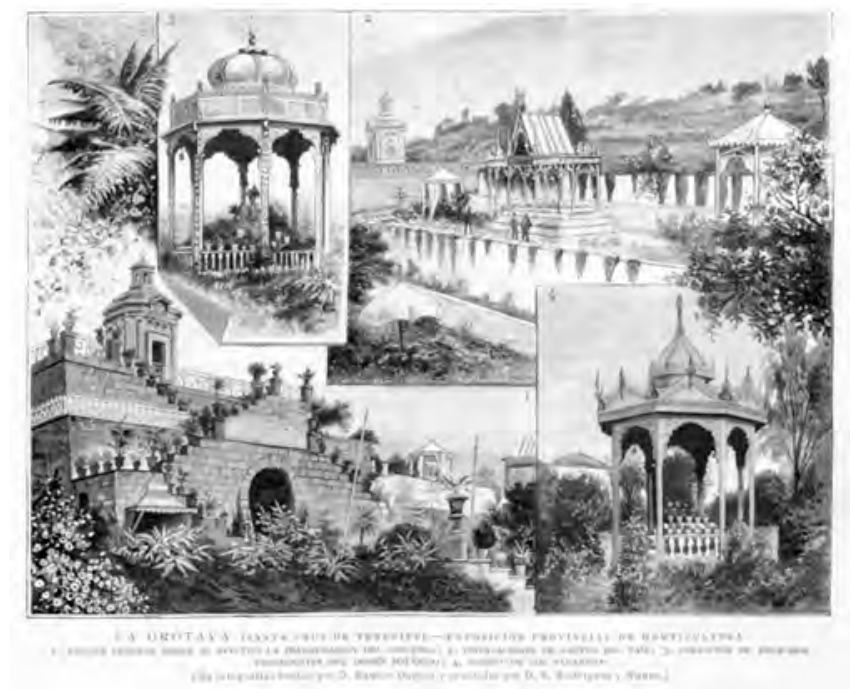

Fig 13. Grabado publicado el 15 de julio de 1888 en La ilustración española y americana, a partir de las fotografías de Ramiro Dugour.

tura y como en ocasiones anteriores la publicación se hace eco, incluyendo graba$\operatorname{dos}^{118}$. Singular fue la exposición de Filipinas celebrada en el palacio de Cristal en el verano de 1887, en cuyas láminas pueden verse singulares ejemplos de arquitectura efímera ${ }^{119}$. Será esta misma revista la que publique también las ilustraciones de la exposición en los jardines de la marquesa, con los magníficos kioscos diseñados por González Borges. Todos ellos, los canarios y los del resto del país, tenían una función en origen ornamental y evocadora muy del espíritu de la época, a veces incluso con mensajes grandilocuentes o de exhaltación de valores en defensa de la nación o de sus poderes, caso de la monarquía.

A través de algunas fotografías tomadas durante la exposición podemos estudiar la estructura y formas eclécticas de estos kioscos, ubicados en diversos lugares del recinto. A partir de algunas de estas instantáneas tomadas por Ramiro Dugour, que mostraban cuatro perspectivas del jardín, se realizó una composición que fue publicada en el mes de julio en la citada La ilustración española y americana $^{120}$ (fig. 13). Acompañaba al grabado un extenso artículo firmado por Eusebio Martínez de Velasco en el que recogía lo ya expuesto en los periódicos locales. En el grabado aparecían al menos cuatro kioscos diferentes, tres de ellos estaban muy cerca del mausoleo y tenían una clara inspiración oriental; un quinto, destinado a la

${ }^{118}$ La ilustración española y americana, $\mathrm{n} .{ }^{\circ} \mathrm{XxIII}, 22$ de junio de 1887.

119 La ilustración española y americana, n. ${ }^{\circ} \mathrm{xxv}, 8$ de julio de 1887 y n. ${ }^{\circ} \mathrm{xxxI}, 22$ de agosto de 1887; y n. ${ }^{\circ}$ XxxviII, 15 de octubre de 1887.

${ }^{120}$ La ilustración española y americana, 15 de julio de 1888. 


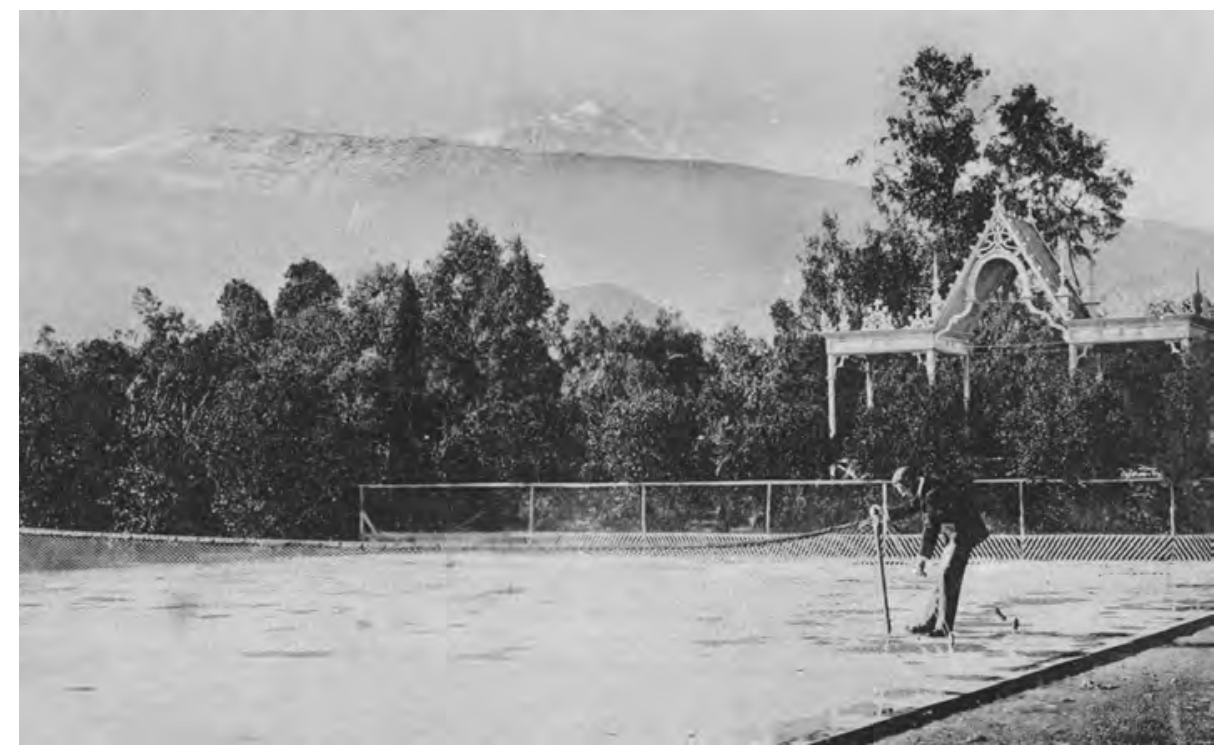

Fig. 14. Kiosco de frutos del país junto a la cancha de tenis de los jardines del Hotel Taoro, c. 1910.

música, se situaba en un promontorio a la entrada del recinto. Usaremos la denominación siguiente para referirnos a ellos, a partir de la mencionada en el pie de foto del grabado y que también aparece en otras referencias de la época: kioscos de frutos del país, kiosco de helechos, kiosco de los coleus y kiosco de la música. En general, se trata de estructuras bastante sólidas inspiradas en los pabellones usados en jardines ingleses, que utilizan formas de la arquitectura colonial británica en Asia, del mudéjar español o del eclecticismo imperante. Como hemos visto, este tipo de construcciones proliferaron en los inicios de las exposiciones universales y se difundieron a través de ilustraciones en catálogos que recogían formas bastante concretas de elaboración de elementos ornamentales que también sirvieron para la decoración exterior en casas de tipo victoriano. Veamos cada uno de los ejemplos.

Los kioscos de frutos del país son dos ejemplos bastante evidentes de la influencia de los pabellones usados en las distintas exposiciones realizadas en España y que aparecían en los grabados de las revistas. El primero de ellos, de base rectangular elevada y rematado por un pronunciado tejado, remite a numerosos ejemplos, como el pabellón del jurado de la exposición de Filipinas de 1887, celebrada en el parque del Retiro de Madrid ${ }^{121}$. Podemos verlo con más detalle en una fotografía tomada en los jardines del Hotel Taoro, junto a una cancha de tenis ${ }^{122}$ (fig. 14). El

121 La ilustración española y americana, 15 de octubre de 1887.

122 Fondos de la FEDAC, n. ${ }^{\circ} 01441$. 
segundo de ellos, del tipo de pabellón circular cubierto, venía utilizándose en todas las exhibiciones, como en la gran exposición de horticultura de 1882. Se trataba de la forma expositiva más básica, a veces cubierta con toldo, aunque en el caso que nos ocupa lo fue con madera. Ambos modelos podemos verlos en pabellones de la exposición de Minería y Artes Metalúrgicas, celebrada en el parque del Retiro de Madrid, o la de horticultura de Valencia, y reproducidos en diversos números de La ilustración española y americana en $1883^{123}$. Los dos kioscos y su disposición en los parterres del jardín Victoria parecen inspirarse también en la estructura que se aprecia en un grabado del real de la Feria de Córdoba, celebrada en 1887 y que apareció publicado en ese año junto a otro de la exposición de horticultura del Retiro madrileño ${ }^{124}$.

El kiosco de los helechos, usado para colocar ejemplares procedentes del Jardín Botánico, recuerda a los diseños de algunos pabellones de la exposición de animales y plantas celebrada en 1882 en la Casa de Campo de Madrid. Se trata de modelos de gusto mudéjar, con arcos de herradura e intensa marquetería en todos los remates y cubiertos con pequeñas cúpulas. Este kiosco evidencia el gusto por la arquitectura árabe que tanto se desarrolló en España en esta época y de la que hay bellísimos ejemplos en Madrid, Barcelona o Sevilla, pero también en Santa Cruz de Tenerife, Las Palmas de Gran Canaria e incluso en la propia Orotava. Por ejemplo, el parecido es manifiesto con el kiosco que se colocará en 1916 en la plaza de la Constitución, del que hablaremos más adelante; pero también recuerda al patio nazarí de la casa Ascanio, actual Hotel Alhambra, diseñada por Mariano Estanga en 1925. Estos tres casos muestran la tendencia de la sociedad hacia elementos románticos de la estética mudéjar, que estaba siendo reinterpretada desde finales del siglo xIx.

El kiosco de los coleus es probablemente el más bello y elegante de todos los que se construyeron para la exposición. Su forma octogonal, con finas columnas separadas por arcos de herradura, los remates en forma de tímpano y el elemento central que lo corona, denotan un conocimiento bastante notorio de las tendencias estéticas del momento, marcadas por la libertad ecléctica y la mezcla de influencias de origen oriental. En su estructura recuerda al pabellón construido para la ocasión con motivo de la visita de los reyes Alfonso XII y María Cristina al Ferrol en $1881^{125}$; e incluso su remate remite al pabellón que la Sociedad de Agricultura de Valencia levantó en $1887^{126}$ (fig. 15).

El kiosco de la música fue colocado sobre un promontorio a la entrada del recinto expositivo, una vez traspasada la portada de entrada, con la verja diseńada por Felipe Machado y que estaba flanqueada por dos pilares rematados por jarrones, antecedente claro del diseño que se usará posteriormente en el cerramiento de la Hijuela del Botánico. Su base era octogonal y estaba elevada, algo muy frecuente

${ }^{123}$ La ilustración española y americana, 8 de julio y 30 de agosto de 1883.

${ }^{124}$ La ilustración española y americana, 2 de junio de 1887.

125 La ilustración española y americana, 22 de agosto de 1881.

126 La ilustración española y americana, 30 de agosto de 1887. 


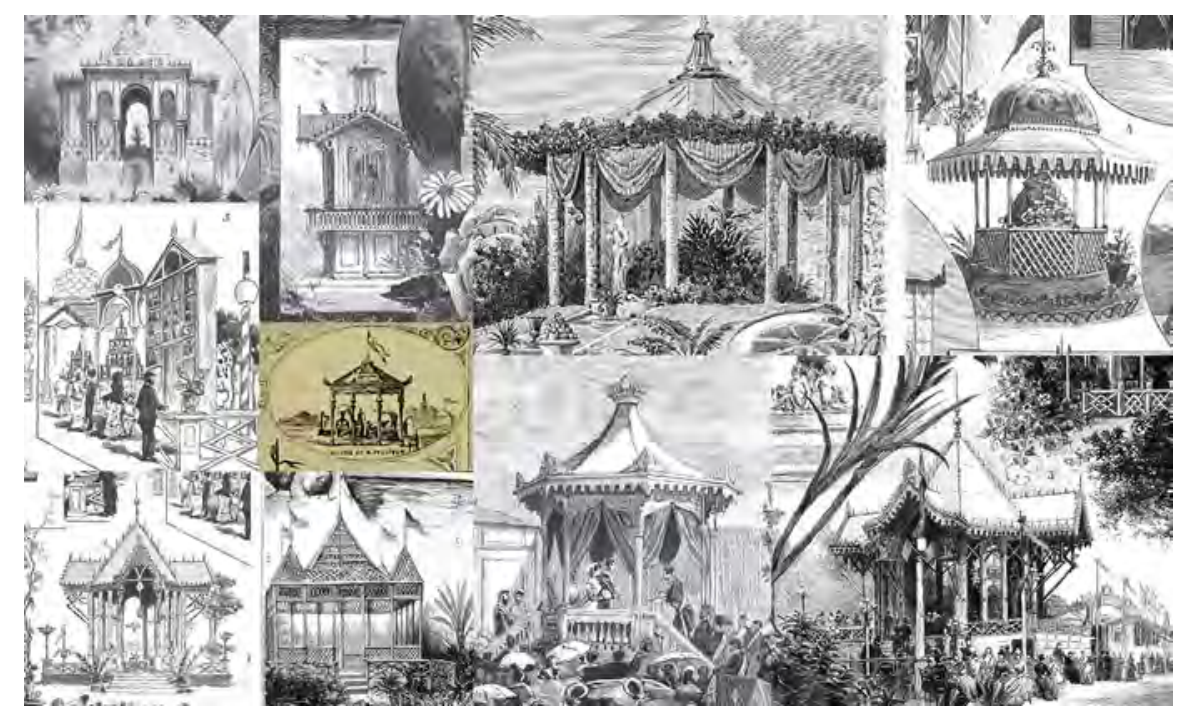

Fig. 15. Distintos modelos de kioscos aparecidos en diversas publicaciones antes de 1888.

en este tipo de kioscos, ya que permitía la escucha y la visualización. Las delgadas columnas facilitaban el desarrollo de estructuras diáfanas y sin ángulos muertos, lo que ayudaba a la expansión del sonido y a que la orquesta, banda o grupo pudiese ser escuchada desde cualquier punto. La cubierta no era muy elevada, pero hacía las funciones de protección de los músicos frente a las inclemencias y al mismo tiempo hacía de caja de resonancia.

Sobre este kiosco tenemos algo más de información. Podemos afirmar que fue trasladado, una vez terminada la muestra, a la cercana plaza de la Constitución. Este es uno de los espacios públicos ajardinados más antiguos de La Orotava, cuya denominación ostenta desde el año 1820. Se la conoció mucho antes como Llano de San Roque, por estar allí la ermita de este santo, en el lugar que luego ocupó el convento de San Agustín y durante bastante tiempo fue llamada La Alameda, por los paseos arbolados que la conformaban. Esta última denominación aludía probablemente al plan urbanístico diseñado en las primeras décadas del siglo xix consistente en convertir el antiguo llano en un espacio donde pasear bajo la sombra de los árboles. Tenemos la suerte de que haya llegado hasta nosotros una imagen demostrativa de ese nuevo aspecto gracias a una acuarela del escultor Fernando Estévez, una de sus pocas incursiones conocidas en la pintura, fechada en $1830^{127}$. En ella vemos un amplio espacio llano rodeado de edificaciones en tres de sus lados, destacando

${ }^{127}$ Como señala Gerardo Fuentes, se trataría del intento de dejar constancia de un plan urbanístico municipal. Véanse Alloza Moreno, Manuel Ángel (1981): La pintura en Canarias en 
la imponente iglesia conventual y por su frente un enorme muro de piedra a modo de talud. Observamos también una veintena de árboles recién plantados de forma simétrica, bancos de piedra entre ellos y distintas personas que pasean o conversan sentadas. Es una valiosa postal de la época y de los cambios urbanos habidos en La Orotava de la primera mitad del siglo xIx. Sin duda, el Llano de San Roque fue desde siempre el lugar público por excelencia, a falta de una plaza concebida como tal, como pasó en La Laguna con la plaza del Adelantado. Tenía otras características que la hacían ideal para la concentración vecinal, tales como sus dimensiones amplias en un espacio abierto y el hecho de ser plana, en un lugar donde la tónica habitual es la pendiente del terreno. Esta primera urbanización de la que dejó constancia Estévez fue a su vez reformada en 1902, dado el estado deplorable en el que se encontraba, incluidos los árboles, y consistió en el ensanche de los paseos, aunque eso hiciera desaparecer alguno de ellos. $\mathrm{Al}$ año siguiente varios vecinos donaron plantas para colocar en la recién reformada plaza. De nuevo en 1916 se hizo uno de los cambios más singulares, decidiéndose sustituir el antiguo kiosco de madera por otro de cemento armado en estilo neomudéjar, de la mano de Nicolás y Diego Álvarez, con la colaboración del maestro Granados ${ }^{128}$. Ese kiosco de madera anterior no era otro que el usado para la exposición de horticultura como pabellón de música y que debió ser trasladado allí hacia 1889. Esta circunstancia puede comprobarse comparando dos fotografías. Por un lado, una de las instantáneas tomadas de la entrada del recinto de la exposición y publicada en el libro de Méndez Pérez ${ }^{129}$. En ella puede apreciarse el kiosco al fondo, sobre un promontorio. En segundo lugar, comparamos una de las numerosas fotografías de la plaza de la Constitución, en la que puede verse un grupo de personas que animadamente conversan a la espera de algún evento y en la que se ve claramente el kiosco que había sido construido para la exhibición en $1888^{130}$. Y allí permaneció hasta agosto de 1916, ya que en esa fecha la revista El Campo se hace eco de la instalación de un nuevo kiosco diseñado por los hermanos Álvarez, señalando que el antiguo se había trasladado a la plaza de Franchy Alfaro como kiosco de música y solicitando que junto a él se instalase también una elegante pajarera con ejemplares canarios ${ }^{131}$. No obstante, no podemos afirmar con seguridad que ese segundo traslado se llevase a efecto. En cualquier caso, debemos recordar que este tipo de kioscos se entendía como lugar de apertura de la música a todos los sectores de la sociedad, favoreciendo su difusión y la sociabilidad a ella asociada. Por extensión, facilitó la coexistencia de distintos modelos arqui-

el siglo XIX. Aula de Cultura de Tenerife, p. 150; y Fuentes Pérez, Gerardo (2014): «Fernando Estévez», en Biblioteca de Artistas Canarios, n. ${ }^{\circ}$ 50. Gobierno de Canarias, p. 106 y siguientes.

128 Financiado por Félix Reyes Martín con 4000 pesetas, 3100 de ellas con la condición de tener la concesión del bar previsto en los bajos del kiosco, durante veinte años.

129 Méndez Pérez, op. cit., p. 24.

${ }^{130}$ Fotografía de Ernesto Fernando Baena, fondos de la FEDAC, n. ${ }^{\circ} 01524$.

131 El Campo, 15 de agosto de 1916. 


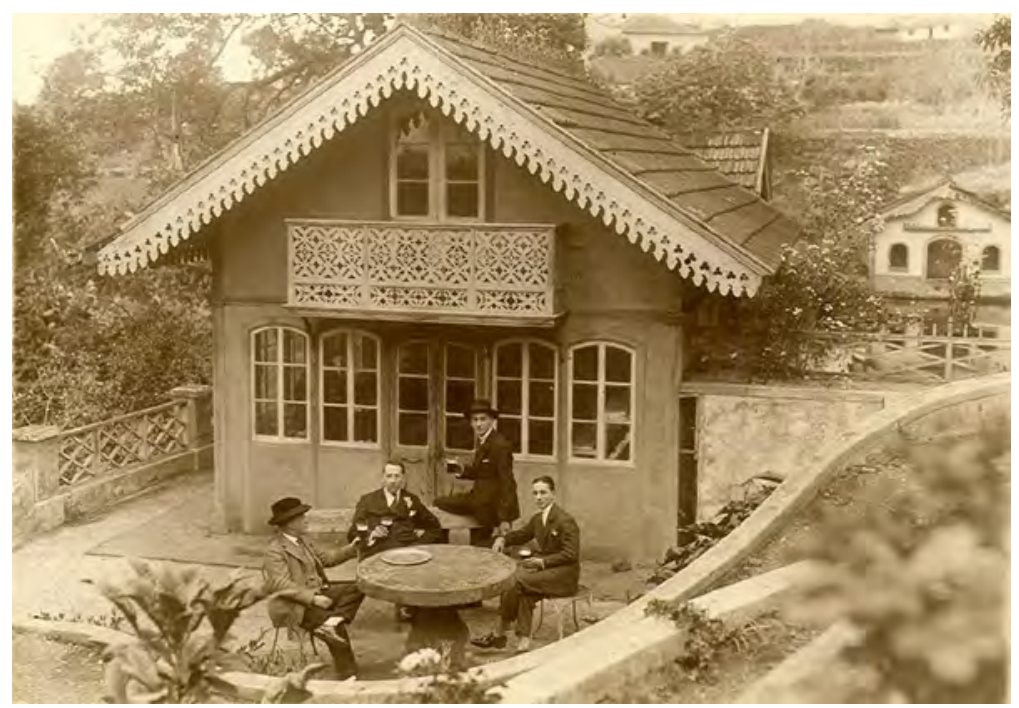

Fig. 16. Antiguos herbarios de la muestra del tipo cottage, ya desaparecidos.

tectónicos, sin olvidar que nació unido al jardín, que fue su razón de ser primera, como lugar de placer en medio de la naturaleza controlada ${ }^{132}$.

En otra serie de fotografías tomadas durante el certamen podemos observar también algunas de las pequeńas casitas del tipo cottage levantadas tanto a la entrada como en otros lugares de la muestra, como la situada junto a la rampa de acceso, de inspiración inglesa, y la situada junto al barranco de Araujo, al fondo de dicha rampa y construida en estilo neogótico, que hizo las veces de herbario de la muestra. Este es un caso sintomático de la influencia victoriana en la arquitectura de la época. En una bella fotografía de principios del siglo xx podemos verla con sus dos cuerpos principales y un tercero más pequeño detrás. Todos en torno a un estanque con decoración central. El uso de la madera calada en los remates del tejado o en el balcón central, las puertas acristaladas de acceso al jardín o la profusa vegetación que la rodea dan idea de la importancia concedida al concepto mismo de jardín como lugar de ocio. Incomprensiblemente esta edificación desapareció en la última reforma del jardín Victoria (fig. 16).

Estos cinco kioscos y las casitas victorianas no fueron los únicos elementos levantados para la exposición de horticultura, aunque sí los de mayores dimensiones y de los que podemos afirmar que tenían estructuras más sólidas. Y aunque su origen les concedía un eminente carácter efímero, lo cierto es que aún pervivie-

132 Sobre esta idea véase Ugalde Gorostiza, Ana Isabel y Otaduy Tristán, Arantza (2011): «El kiosco de la música de la plaza del ensanche de Irún (1903), obra del arquitecto Javier Aguirre Iturralde», en Ars bilduma. Universidad del País Vasco, p. 139. 
ron unos años más en el propio jardín Victoria o en los jardines del Hotel Taoro, tal y como hemos visto. La realidad es que González Borges tuvo que conocer algunas de las publicaciones en las que estampas y grabados reproducían estos pabellones expositivos, de diversa índole y estilo, y a partir de ahí diseñar los que iban a utilizarse en la muestra. Pero creemos que también tuvo que consultar algunos de los manuales sobre construcción de todo tipo que se publicaron a lo largo del siglo XIX, especialmente aquellos que iban dirigidos a un público menos especializado y que incluían modelos para kioscos. Lo que demuestra que se trataba de un personaje con una formación importante y con una visión del bien común singularmente desarrollada y que proyectaría en otros campos en su villa natal.

Recibido: 03-04-2019. Aceptado: 11-04-2019 
